Atmos. Chem. Phys., 10, 5371-5389, 2010

www.atmos-chem-phys.net/10/5371/2010/

doi:10.5194/acp-10-5371-2010

(C) Author(s) 2010. CC Attribution 3.0 License.

\title{
Determination of particulate lead using aerosol mass spectrometry: MILAGRO/MCMA-2006 observations
}

\author{
D. Salcedo ${ }^{1}$, T. B. Onasch ${ }^{2}$, A. C. Aiken ${ }^{3,}$, L. R. Williams ${ }^{2}$, B. de Foy ${ }^{4}$, M. J. Cubison ${ }^{3}$, D. R. Worsnop ${ }^{2}$, \\ L. T. Molina ${ }^{5,6}$, and J. L. Jimenez ${ }^{3}$ \\ ${ }^{1}$ Centro de Investigaciones Químicas, Universidad Autónoma del Estado de Morelos, Cuernavaca, México \\ ${ }^{2}$ Center for Aerosol and Cloud Chemistry, Aerodyne Research, Billerica, MA, USA \\ ${ }^{3}$ Cooperative Institute for Research in the Environmental Sciences (CIRES) and Department of Chemistry and Biochemistry, \\ University of Colorado, Boulder, CO, USA \\ ${ }^{4}$ Department of Earth and Atmospheric Sciences, Saint Louis University, Saint Louis, MO, USA \\ ${ }^{5}$ Molina Center for Energy and the Environment, La Jolla, CA, USA \\ ${ }^{6}$ Earth Atmospheric and Planetary Sciences Department, Massachusetts Institute of Technology, Cambridge, MA, USA \\ *now at: ETH, Zurich, Switzerland
}

Received: 14 January 2010 - Published in Atmos. Chem. Phys. Discuss.: 3 February 2010

Revised: 5 May 2010 - Accepted: 25 May 2010 - Published: 20 June 2010

\begin{abstract}
We report the first measurements of particulate lead $(\mathrm{Pb})$ from Aerodyne Aerosol Mass Spectrometers, which were deployed in and around Mexico City during the Megacity Initiative: Local and Global Research Observations (MILAGRO)/Mexico City Metropolitan Area 2006 (MCMA-2006) field campaigns. The high resolution mass spectrometer of one of the AMS instruments (HR-AMS) and the measured isotopic ratios unequivocally prove the detection of $\mathrm{Pb}$ in ambient particles. A substantial fraction of the lead evaporated slowly from the vaporizer of the instruments, which is indicative of species with low volatility at $600^{\circ} \mathrm{C}$. A model was developed in order to estimate the ambient particulate $\mathrm{Pb}$ entering the AMS from the signals in the "open" and the "closed" (or "background") mass spectrum modes of the AMS. The model suggests the presence of at least two lead fractions with $\sim 25 \%$ of the $\mathrm{Pb}$ signal exhibiting rapid evaporation (1/e decay constant, $\tau<0.1 \mathrm{~s}$ ) and $\sim 75 \%$ exhibiting slow evaporation $(\tau \sim 2.4 \mathrm{~min})$ at the $\mathrm{T} 0$ urban supersite and a different fraction (70\% prompt and 30\% slow evaporation) at a site northwest from the metropolitan area (PEMEX
\end{abstract}

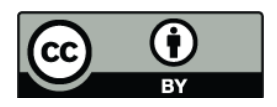

Correspondence to: J. L. Jimenez (jose.jimenez@colorado.edu) site). From laboratory experiments with pure $\mathrm{Pb}\left(\mathrm{NO}_{3}\right)_{2}$ particles, we estimated that the $\mathrm{Pb}$ ionization efficiency relative to nitrate $\left(\mathrm{RIE}_{\mathrm{Pb}}\right)$ is 0.5 . Comparison of time series of AMS $\mathrm{Pb}$ with other measurements carried out at the T0 supersite during MILAGRO (using Proton Induced X-ray Emission (PIXE), Inductively-Coupled Plasma Mass Spectrometry (ICP-MS) and single-particle counts from an Aerosol Time-of-Fight Mass Spectrometer (ATOFMS)) shows similar levels (for PIXE and ICP-MS) and substantial correlation. During part of the campaign, sampling at $\mathrm{T} 0$ was alternated every 10 min with an Aerosol Concentrator, which enabled the detection of signals for $\mathrm{PbCl}^{+}$and $\mathrm{PbS}^{+}$ions. $\mathrm{PbS}^{+}$displays the signature of a slowly evaporating species, while $\mathrm{PbCl}^{+}$appears to arise only from fast evaporation, which is likely due to the higher vapor pressure of the compounds generating $\mathrm{PbCl}^{+}$. This is consistent with the evaporation model results. Levels of particulate $\mathrm{Pb}$ measured at $\mathrm{T} 0$ were similar to previous studies in Mexico City. $\mathrm{Pb}$ shows a diurnal cycle with a maximum in the early morning, which is typical of primary urban pollutants. Pb shows correlation with $\mathrm{Zn}$, consistent with previous studies, while the sources of $\mathrm{Pb}$ appear to be at least partially disjoint from those of particulate chloride. Back trajectory analysis of the $\mathrm{T} 0 \mathrm{~Pb}$ data suggests the presence of sources inside the urban area SSW and

Published by Copernicus Publications on behalf of the European Geosciences Union. 
$\mathrm{N}$ of $\mathrm{T} 0$, with different chemical forms of $\mathrm{Pb}$ being associated with different source locations. High signals due to particulate lead were also detected in the PEMEX site; again, no correlation between $\mathrm{Pb}$ and chloride plumes was observed, suggesting mostly different sources for both species.

\section{Introduction}

Lead is considered a criteria air pollutant with a wide range of health effects depending on the level of exposure. Lead exposure has been associated with neurotoxic effects and enhanced risk of increased blood pressure and hypertension. Other negative health associations with lead include effects on renal, immune and reproductive systems, as well as on the calcium and vitamin D metabolism (EPA, 2006). In response to recent evidence of the occurrence of health effects at appreciably lower blood $\mathrm{Pb}$ levels than those demonstrated previously, the US Environmental Protection Agency has recently revised the US National Ambient Air Quality Standard (NAAQS) for lead down to $0.15 \mu \mathrm{g} \mathrm{m}^{-3}$ in total suspended particles (TSP) during a 3-month averaging period (EPA, 2008). The previous US NAAQS for Pb was $1.5 \mu \mathrm{g} \mathrm{m}^{-3}$ and was promulgated in 1978. Furthermore, it has recently been suggested that the presence of anthropogenic lead-containing particles in the atmosphere can have an important climatic effect because they are among the most efficient ice-forming substances commonly found in the atmosphere and, hence, they can affect cloud properties (Cziczo et al., 2009).

Historically, mobile sources were a major source of atmospheric lead due to the use of leaded anti-knock additives in gasoline. The phasing out of $\mathrm{Pb}$ in gasoline started worldwide during the $70 \mathrm{~s}$ and $80 \mathrm{~s}$, and since then the concentration of airborne lead has dramatically decreased (Nriagu, 1990; Pacyna et al., 2009). Most of the current $\mathrm{Pb}$ sources are related to mining, smelters, foundries, industrial fuel combustion, solid waste incineration, and unpaved road dust. The remaining mobile-source related emissions of lead include metallic pieces and brake wear, soil resuspension, and emissions from some types of vehicles that continue to use leaded gasoline (e.g., some types of aircraft and race cars) (Harris and Davidson, 2005; Heal et al., 2005; Lough et al., 2005; EPA, 2006; Murphy et al., 2007; Kummer et al., 2009; Reff et al., 2009).

Atmospheric $\mathrm{Pb}$ is found in the aerosol phase due to the low volatility of lead compounds. The initial form of lead when emitted to the atmosphere depends on the type and conditions of the source. For example, smelting aerosols contain $\mathrm{Pb}, \mathrm{PbS}, \mathrm{PbSO}_{4}, \mathrm{PbO}, \mathrm{PbCO}_{3}$; coal combustion aerosols contain $\mathrm{PbS}$ and $\mathrm{PbSe}$; wood combustion aerosols contain $\mathrm{PbCO}_{3}$; and waste incineration aerosols contain $\mathrm{PbCl}_{2}$ and $\mathrm{PbO}$ (EPA, 2006). X-ray studies of single ambient particles have identified lead in most of these chemical forms in ambient aerosol (vanMalderen et al., 1996; Aragón-Piña et al.,
2000; Ebert et al., 2002; Ishizaka et al., 2009). On the other hand, information is scarce regarding the reactivity of lead compounds in the atmosphere once they are emitted. Moffet et al. (2008a) suggested that $\mathrm{Pb}$ and $\mathrm{Zn}$ containing particles can undergo atmospheric processing where the metal chlorides react with $\mathrm{HNO}_{3(g)}$ to generate the metal nitrates and $\mathrm{HCl}_{(g)}$. Ishizaka et al. (2009) suggested that particle $\mathrm{PbSO}_{4}$ can be converted to $\mathrm{PbCO}_{3}$ in the presence of water.

In Mexico City, reductions in the amount of lead added to gasoline started during the 1980s, and it was completely eliminated in 1997. A considerable decrease in the concentration of atmospheric $\mathrm{Pb}$ was observed since then. In fact, the national standard $\left(1.5 \mu \mathrm{g} \mathrm{m}^{-3}\right.$ in TSP, 3-month averaging period) has not been exceeded since 1993 (SMA, 2007). Lead concentrations in particles after 1997 have been reported in several publications, which are summarized in Fig. 1. Miranda et al. (2004) analyzed particles collected from June to September 2001 with Proton Induced X-ray Emission (PIXE) from three sites in Mexico City and reported 24-h concentrations. Applying a cluster analysis to the data, Miranda et al. (2004) suggested that $\mathrm{Pb}$ was associated with $\mathrm{Mn}, \mathrm{Cu}, \mathrm{Zn}$ and Se. Vega et al. (2004) reported 24-h $\mathrm{Pb}$ concentrations in $\mathrm{PM}_{2.5}$ and $\mathrm{PM}_{10}$ using X-ray fluorescence on samples from three sites in Mexico City in four winter and spring periods from 2000 to 2002. Rosas-Pérez et al. (2007) reported $\mathrm{PM}_{10}$ 24-h Pb concentration determined by PIXE in particles collected from January to June 2002 at three different sites in Mexico City. During MILAGRO, three published papers report time series of particle $\mathrm{Pb}$ in the Mexico City Metropolitan Area (MCMA) using InductivelyCoupled Plasma Mass Spectrometry (ICP-MS) after acidic digestion of particle filters (Moreno et al., 2008; Querol et al., 2008; Mugica et al., 2009). Time trends of Pb-containing particle counts were also measured with an Aerosol Timeof-Fight Mass Spectrometer (ATOFMS; Moffet et al., 2008a, b). Moffet et al. (2008a) also reports time trends of particle $\mathrm{Pb}$ at $\mathrm{T} 0$ using PIXE. The ICP-MS, ATOFMS, and PIXE $\mathrm{Pb}$ time series are discussed in more detail in Sect. 3.4. Figure 1 also includes AMS Pb mass concentrations from this work (Sects. 3.1-3.3 describe the method used for their calculation). The levels of $\mathrm{Pb}$ reported during MILAGRO are similar to previously reported levels which suggests that the emissions of $\mathrm{Pb}$ in Mexico City have not substantially changed in the last decade. Furthermore, Querol et al. (2008) pointed out that the levels of $\mathrm{Pb}$ in Mexico City are similar to those in other megacities. In addition, Moffet et al. (2008a) combined ATOFMS data, PIXE and analysis of individual particles using computer controlled scanning electron microscopy with energy dispersive X-ray analysis (CCSEM/EDX) and scanning transmission X-ray microscopy with near edge Xray spectroscopy (STXM/NEXAFS), in order to characterize particles containing $\mathrm{Zn}, \mathrm{Pb}$, and $\mathrm{Cl}$ collected at $\mathrm{T} 0$. With the same objective, Moreno et al. (2008) complemented the ICP-MS data with analysis of particles using an environmental scanning electron microscope (ESEM) and with chemical 


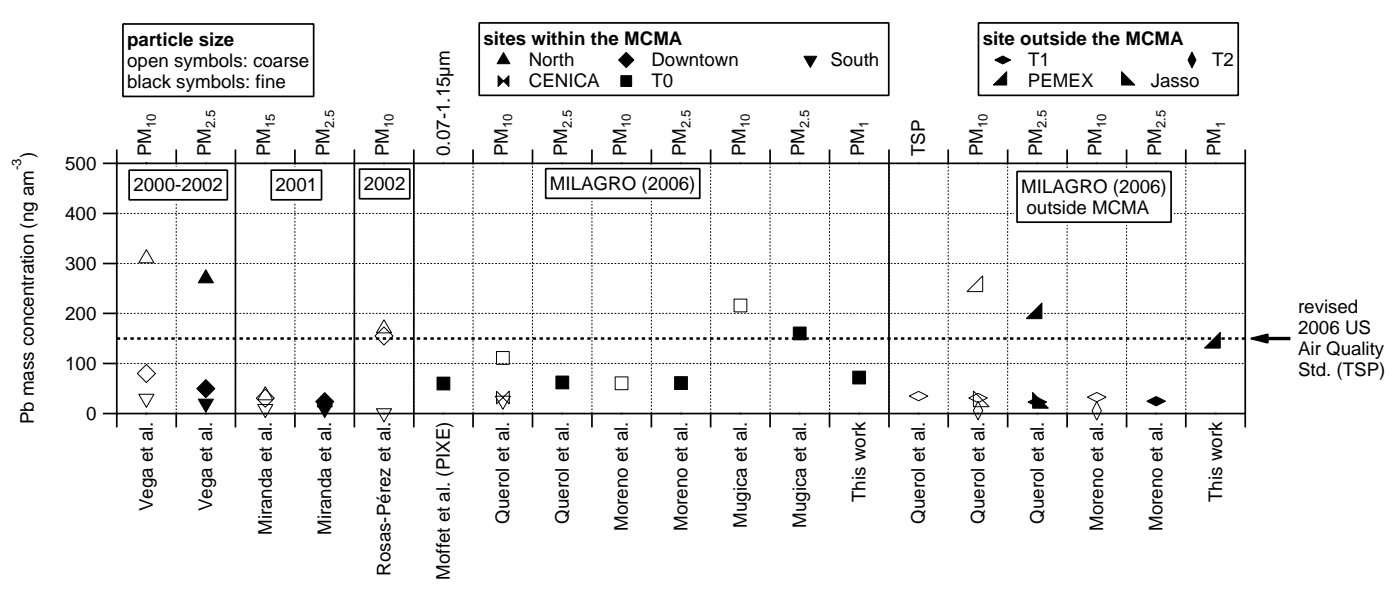

Fig. 1. Summary of particle $\mathrm{Pb}$ measurements within the MCMA since 1997. Boxes on top of the measurements indicate the year in which the samples were collected. North, Downtown and South sites indicate general areas within the MCMA. The approximate location of the sites is marked in Fig. S1. The concentrations for previous publications are assumed to be reported under ambient (and not STP) conditions as this is more common for ground-based studies, although none of the previous papers specifies which convention is used.

analyses of individual particles using dispersive X-ray microanalysis (EDX). Both Moffet et al. (2008a) and Moreno et al. (2008) describe $\mathrm{Pb}$-containing particles as often being internally mixed with other elements such as $\mathrm{Sb}, \mathrm{Cr}$, $\mathrm{Zn}, \mathrm{Cl}, \mathrm{Na}, \mathrm{K}$, and S. Finally, transmission electron microscopy (TEM) together with EDX was used to measure size and composition of nanoparticles $(<50 \mathrm{~nm})$ collected on filters from Mexico City pollution plumes during MILAGRO (Adachi and Buseck, 2010). It was found that $\mathrm{Pb}$ was one of the most abundant metals in the nanoparticles studied which strongly suggests the importance of urban or industrial hightemperature sources, and that about half of the nanoparticles studied containing $\mathrm{Pb}$ also contained $\mathrm{Zn}$.

An Aerodyne High Resolution Time-of-Flight Aerosol Mass Spectrometer (HR-ToF-AMS, referred to as HR-AMS hereafter) (DeCarlo et al., 2006) was deployed at the Instituto Mexicano del Petróleo (IMP) Supersite near downtown Mexico City (referred to as "T0"), during the MILAGRO campaign, which took place in March 2006 (Molina et al., 2010). In addition, a mobile laboratory equipped with an Aerodyne Compact ToF-AMS (C-ToF-AMS, referred as C-AMS hereafter) (Drewnick et al., 2005; Canagaratna et al., 2007) sampled at several sites in and around Mexico City during the MILAGRO campaign (Herndon et al., 2008). Both AMSs measure submicron aerosol concentration and composition with high time resolution. Furthermore, the HR-AMS permits differentiation between ions with the same nominal mass (DeCarlo et al., 2006). In this paper we take advantage of the high time resolution and high $\mathrm{m} / \mathrm{z}$ resolution to report, for the first time, the unequivocal detection of particulate lead using an Aerodyne AMS. Laboratory experiments using pure $\mathrm{Pb}\left(\mathrm{NO}_{3}\right)_{2}$ particles were performed in order to estimate a calibration factor for the AMS (i.e., the ionization efficiency of $\mathrm{Pb}$ relative to nitrate, $\mathrm{RIE}_{\mathrm{Pb}}$ ). The time series of the $\mathrm{PM}_{1}$ (particulate matter less than $1 \mu \mathrm{m}$ in vacuum aerodynamic diameter) $\mathrm{Pb}$ signal at the T0 and "PEMEX" (located $\sim 40 \mathrm{~km}$ north-west of the metropolitan area) sites are presented and compared to other collocated measurements. Finally, several analyses are presented which are enabled by the high time resolution of the AMS particulate $\mathrm{Pb}$ measurements, with the objective of inferring possible source types, locations, and strengths of $\mathrm{Pb}$ emissions in Mexico City: diurnal cycles, correlations of lead with other particulate components, and wind-rose and back-trajectory analyses.

\section{Experimental}

\subsection{MILAGRO/MCMA-2006 campaign}

The Mexico City Metropolitan Area 2006 (MCMA-2006; $\mathrm{http}: / / \mathrm{mce} 2.0 \mathrm{rg} / \mathrm{fc} 06 / \mathrm{fc} 06 . \mathrm{html}$ ) campaign was part of the MILAGRO field experiment which took place in March 2006 (http://www.eol.ucar.edu/projects/milagro/ and Molina et al., 2010). MCMA-2006 focused on emissions and surface concentrations within the Mexico City basin in order to better understand the emissions and processing of pollutants in the MCMA, their dispersion, transport and transformation in the atmosphere, the exposure patterns of the general population to these pollutants, and the effects on human health, and also to provide an initial reference state for studies of the regional evolution of MCMA pollution.

One of the three main ground sampling sites during MILAGRO was T0 (see Fig. S1 in the Supp. Info. section), which was located within the northern part of the MCMA to characterize fresh and processed pollutants representative of the urban area. T0 was located at the Instituto Mexicano del Petróleo (IMP), within a mixed-use neighborhood (small 
industries, residential and commercial), and south of a large area of small industries in Mexico City. A large avenue, with relatively heavy traffic (both light-duty and heavy-duty vehicles) was located $\sim 200 \mathrm{~m}$ from the measurement site.

A mobile laboratory equipped with several atmospheric gas and aerosol instruments (Kolb et al., 2004) sampled at several sites in and around the MCMA during the MILAGRO campaign (Herndon et al., 2008). The PEMEX site was located close to an oil transfer facility, approximately $40 \mathrm{~km}$ north-west from T0 and $20 \mathrm{~km}$ south from a major oil refinery (Tula) within a lightly urbanized area (see Fig. S1).

\subsection{Aerodyne aerosol mass spectrometers}

An HR-AMS was located on the roof of a four-story building at T0 and sampled continuously from 10 March to 30 March 2006. A detailed description of the HR-AMS operation, calibrations, intercomparisons to collocated instruments, and overview of the results during this period have been presented by Aiken et al. $(2008,2009,2010)$ and further analyses of these data have been presented in several papers (Heald et al., 2008, 2010; Zheng et al., 2008; Ervens et al., 2009; Fast et al., 2009; Hodzic et al., 2009, 2010; Huffman et al., 2009; Paredes-Miranda et al., 2009). During the measurement period, average high resolution aerosol mass spectra $(\mathrm{m} / \mathrm{z}, 4-400)$ were saved every $2.5 \mathrm{~min}$, alternating between $\mathrm{V}$ - and $\mathrm{W}$-mode every $5 \mathrm{~min}$. The two modes of operation of the HR-AMS refer to different ion paths in the ToF spectrometer; V-mode is about 10 times more sensitive, but W-mode offers about 2 times higher mass resolution (DeCarlo et al., 2006). During MILAGRO, sampling was alternated every $10 \mathrm{~min}$ from ambient to special interfaces such as a mini Versatile Aerosol Concentration Enrichment System (mini-VACES) (Kim et al., 2001; Khlystov et al., 2005). The mini-VACES uses a virtual impactor to concentrate particles; water supersaturation is used to grow particles prior to their passage through the impactor in order to enlarge the smaller particles so they can also be concentrated. After leaving the virtual impactor, the droplets are dried with a silica-gel diffusion dryer, thus bringing the concentrated aerosol particles back to their original size (Kim et al., 2001). A previous VACES-AMS study showed good performance in terms of similar concentration enhancements for the different species and little perturbation of the mass size distributions. A small artifact was observed for semi-volatile water soluble species such as ammonium and nitrate, for which the concentration on the smaller particles was enhanced after passage through the concentrator; however, the amount of the extra material was rather small (Khlystov et al., 2005), and this effect is not expected to affect the concentration of a non-volatile species such as $\mathrm{Pb}$.

A C-AMS was deployed in the Aerodyne Mobile Laboratory (AML). One minute ambient averaged mass spectra $(\mathrm{m} / \mathrm{z}, 4-400,50 \%$ duty cycle with PToF mode) with unit resolution were obtained with this instrument sampling behind a $\mathrm{PM}_{2.5}$ cyclone. Previous measurements of the AML during MILAGRO have been reported by Thornhill et al. (2008), Herndon et al. (2008), Zavala et al. (2009), and Wood et al. (2009, 2010).

During the operation of both AMSs, a chopper modulates the transmission of the sampled aerosol beam to the particle detector by continually switching between the "closed" and "open" positions (blocks the beam completely, or transmits the beam completely, respectively) every few seconds ( $\sim 3 \mathrm{~s})$. Then, a thermal desorption technique, in which the beam of the sampled ambient particles hits a hot porous tungsten inverted conical surface for vaporizing particulate compounds, is used prior to ionization and detection using time-of-flight mass spectrometry (Canagaratna et al., 2007). During MILAGRO, the C-AMS vaporizer operated at $\sim 550^{\circ} \mathrm{C}$ and the HR-AMS at $\sim 600^{\circ} \mathrm{C}$. In general, the closed signal represents the instrument background signal and it is typically small for the non-refractory aerosol components (i.e., that flash evaporate at the vaporizer temperature) such as sulfate, nitrate, ammonium, and organics (Huffman et al., 2009).

All raw AMS signals presented here have been corrected for small variations in detection sensitivity (i.e., airbeam correction, Allan et al., 2003; and converted to mass in "nitrateequivalent mass concentrations" - Nitr.-eq., Jimenez et al., 2003). A collection efficiency (CE) of 0.5 has been applied, which accounts for detection losses mainly due to bounce of particles off the vaporizer (Canagaratna et al., 2007). We performed laboratory experiments that indicate that pure lead salt particles exhibit CE of less than $40 \%$, most likely due to significant particle bounce from the vaporizer surface. However, if $\mathrm{Pb}$ were internally mixed with other non-refractory material, then lead signals would exhibit a CE similar to other measurable chemical species (i.e., organics, nitrate, sulfate, ammonium, and chloride). The value of 0.5 for $\mathrm{CE}$ was chosen because T0 particles exhibit a significant degree of internal mixing of $\mathrm{Pb}$ with other chemical species such as elemental carbon (EC) and organic compounds (Moffet et al., 2008a), and because this value has resulted in good agreement with a wide variety of particulate instruments in the MCMA (Salcedo et al., 2006; Kleinman et al., 2008; Aiken et al., 2009). The value of 0.5 is further supported by comparisons of AMS particle $\mathrm{Pb}$ mass concentrations with measurements performed with other instruments, which show similar concentrations and good correlation (see Sect. 3.4).

Aerosol mass concentrations are reported in $\mathrm{ng} \mathrm{m}^{-3}$ or $\mu \mathrm{g} \mathrm{m}^{-3}$ at local ambient pressure and temperature conditions; we use the symbol of $\mathrm{ng} \mathrm{am}^{-3}$ or $\mu \mathrm{g} \mathrm{am}^{-3}$ to make clear that the measurements are reported under ambient conditions. Concentrations under standard conditions $\left(\mu \mathrm{g} \mathrm{sm}^{-3}\right.$ under STP, $273 \mathrm{~K}, 1 \mathrm{~atm}$ ) can be estimated by multiplying our concentrations by 1.42. All time series are reported in local standard time, which corresponds to US Central Standard Time (CST) or Coordinated Universal Time (UTC) minus $6 \mathrm{~h}$. All linear regressions were performed using a "robust 2-sided method" in Igor Pro 6.1, where the sum of the 

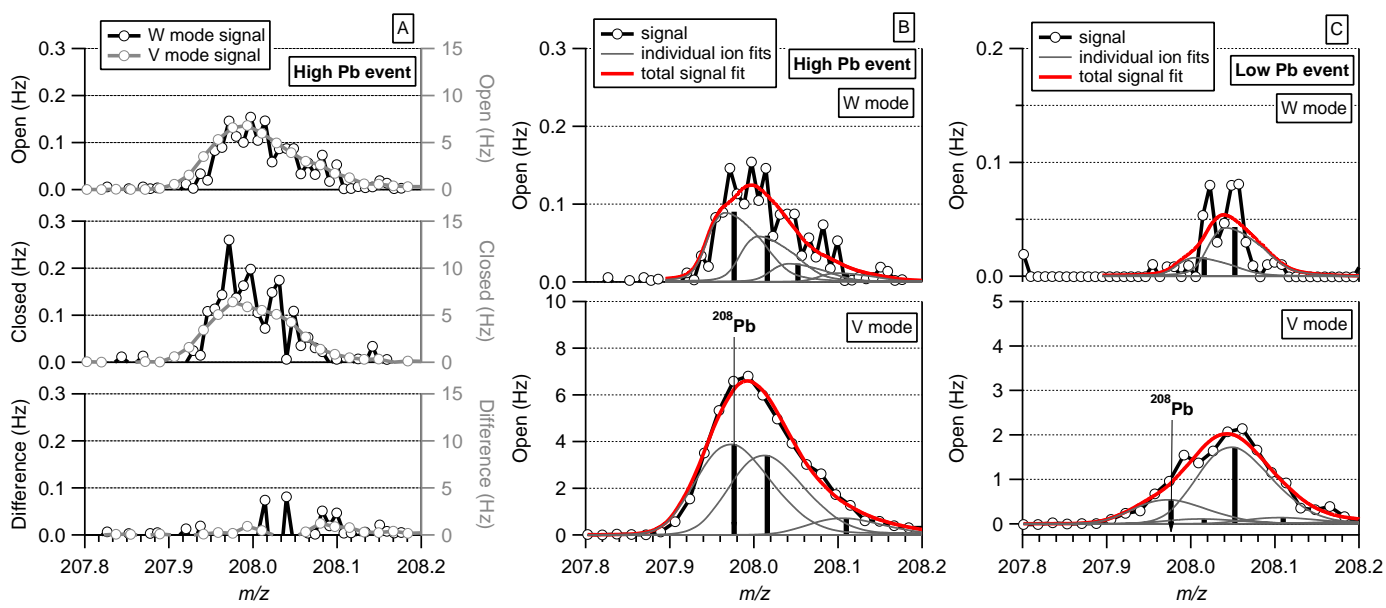

Fig. 2. 2.5 min averaged open $V$ and $\mathrm{W}$ mass spectra at $\mathrm{m} / \mathrm{z} 208$ obtained with the HR-AMS located at T0. Panel (A) compares open, closed and difference mass spectra for $\mathrm{V}$ and $\mathrm{W}$ modes. Panels $(\mathbf{B})$ and $(\mathbf{C})$ compare $\mathrm{V}$ and $\mathrm{W}$ mode open mass spectra at time periods with high and low $\mathrm{Pb}$ signal respectively (see Fig. 6). Black and grey lines and circles correspond to the AMS raw signal. Grey lines in panels B and $\mathrm{C}$ are modified Gaussian functions that represent the signal of individuals ions whose exact mass is indicated by the vertical black lines. The height of the vertical lines corresponds to the height of the modified Gaussian functions. Red lines are the sum of the individual ion peaks and represent the fitted total signal at the given nominal $\mathrm{m} / \mathrm{z}$.

absolute deviations is minimized rather than the squares of the deviations, which tends to de-emphasize outlier values (WaveMetrics, 2008).

\section{Results and discussion}

\subsection{Identification of lead in the AMS mass spectra}

Figure 2 shows 2.5 min averaged spectra of ambient aerosol at nominal $\mathrm{m} / \mathrm{z}, 208$ obtained with the HR-AMS located at T0. Panel A compares V- and W-mode open, closed and difference (open minus closed) spectra, during a period with a high lead signal (marked in Fig. 6). The difference between the sensitivity and the resolution of $\mathrm{V}$ - and $\mathrm{W}$-modes is evident in the figure; W-mode spectra have more resolution but a noisier signal. Typically, the difference mass spectra correspond to the sampled aerosol, once the background gases in the detection region are accounted for by subtracting the closed from the open mass spectra (Canagaratna et al., 2007). However, in the case of lead ions, a closed signal of the same order of magnitude as the open signal was observed which, as it will be explained later, indicates that there is a residual signal caused by aerosol components that evaporate slowly from the vaporizer due to their relatively low volatility (Huffman et al., 2009). Because of this slow evaporation, the difference signal cannot be interpreted as usual in the case of lead ions and will not be discussed further. Panel B in Fig. 2 shows the same open raw signals as Panel A together with spectral fits obtained assuming the presence of several individual ions whose signals have a modified Gaussian shape (DeCarlo et al., 2006). The atomic weight of the most abundant lead isotope $\left({ }^{208} \mathrm{~Pb}\right)$ is marked. The other fragments marked were selected in order to allow a more accurate fitting of the raw MS signal. They are most likely organic ions that contain $\mathrm{C}, \mathrm{H}, \mathrm{O}$ and/or $\mathrm{N}$; however, their exact identification is beyond the scope of this paper. Panel $\mathrm{C}$ in Fig. 2 is similar to panel B, but shows the spectra during a period with very low $\mathrm{Pb}$ signal (marked in Fig. 6). Signals corresponding to ions of the other main lead isotopes $\left({ }^{207} \mathrm{~Pb}^{+}\right.$and $\left.{ }^{206} \mathrm{~Pb}^{+}\right)$, as well as to the doubly charged ions of the three main lead isotopes $\left({ }^{208} \mathrm{~Pb}^{++},{ }^{207} \mathrm{~Pb}^{++}\right.$and ${ }^{206} \mathrm{~Pb}^{++}$), were also observed (see Figs. S2 and S3). No signal for ${ }^{204} \mathrm{~Pb}^{+}$was observed, as expected due to its low abundance $\left(0.027\right.$ relative to ${ }^{208} \mathrm{~Pb}^{+}$, (deLaeter et al., 2003)) and the limited signal-to-noise of our measurements.

Given the uncertainties of the fitting method, it is important to examine the ratios of the different lead isotopes to confirm that the signals are indeed due to lead. Figure 3 shows scatter plots of the singly and doubly charged ions of ${ }^{207} \mathrm{~Pb}$ and ${ }^{206} \mathrm{~Pb}$ vs. ${ }^{208} \mathrm{~Pb}$ along with the expected isotopic ratio (deLaeter et al., 2003). Expected values of the isotopic ratios and the results of the linear fits - slope $(\mathrm{m})$ and Pearson's $R$ - are listed in Table 1. The scatter in the data is larger for W-mode because of the lower sensitivity of the instrument in this mode. However, all ions show the expected isotopic abundance within the noise of the measurement, which provides evidence that the signals correspond to lead and not to other ions with a similar exact mass. Furthermore, scatter plots of doubly vs. singly charged $\mathrm{Pb}$ ions show a good correlation and similar slopes of the order of $\mathrm{Pb}^{++} / \mathrm{Pb}^{+} \sim 50 \%$ (see Fig. S4). The slope of such scatter plots is related to the difference in ionization efficiency for the singly and doubly charged ions, which should be the 
Table 1. Expected (deLaeter et al., 2003) and calculated lead isotopic ratios from linear fits (see Figs. 3 and 5); slope ( $m$ ) and Pearsons $R$ are shown.

\begin{tabular}{|c|c|c|c|c|c|c|c|c|c|c|c|c|c|}
\hline & \multirow[b]{3}{*}{$\begin{array}{c}\text { natural } \\
\text { isotopic ratio }\end{array}$} & \multicolumn{6}{|c|}{ from open signal } & \multicolumn{6}{|c|}{ from closed signal } \\
\hline & & \multicolumn{2}{|c|}{ V-mode } & \multicolumn{2}{|c|}{ W-mode } & \multicolumn{2}{|c|}{ C-AMS } & \multicolumn{2}{|c|}{ V-mode } & \multicolumn{2}{|c|}{ W-mode } & \multicolumn{2}{|c|}{ C-AMS } \\
\hline & & $m$ & $R$ & $m$ & $R$ & $m$ & $R$ & $m$ & $R$ & $m$ & $R$ & $m$ & $R$ \\
\hline${ }^{206} \mathrm{~Pb}^{+}{ }^{208} \mathrm{~Pb}^{+}$ & 0.460 & 0.37 & 0.97 & 0.47 & 0.92 & 0.49 & 1.0 & 0.41 & 0.96 & 0.47 & 0.85 & 0.49 & 0.99 \\
\hline${ }^{207} \mathrm{~Pb}^{+} /^{208} \mathrm{~Pb}^{+}$ & 0.422 & 0.38 & 0.98 & 0.36 & 0.86 & 0.43 & 1.0 & 0.38 & 0.97 & 0.34 & 0.76 & - & - \\
\hline${ }^{206} \mathrm{~Pb}^{++}{ }^{208} \mathrm{~Pb}^{++}$ & 0.460 & 0.37 & 0.80 & 0.43 & 0.73 & - & - & 0.42 & 0.83 & 0.40 & 0.59 & - & - \\
\hline${ }^{207} \mathrm{~Pb}^{++} / 208 \mathrm{~Pb}^{++}$ & 0.422 & 0.51 & 0.94 & 0.66 & 0.58 & - & - & 0.5 & 0.93 & 0.42 & 0.71 & - & - \\
\hline
\end{tabular}

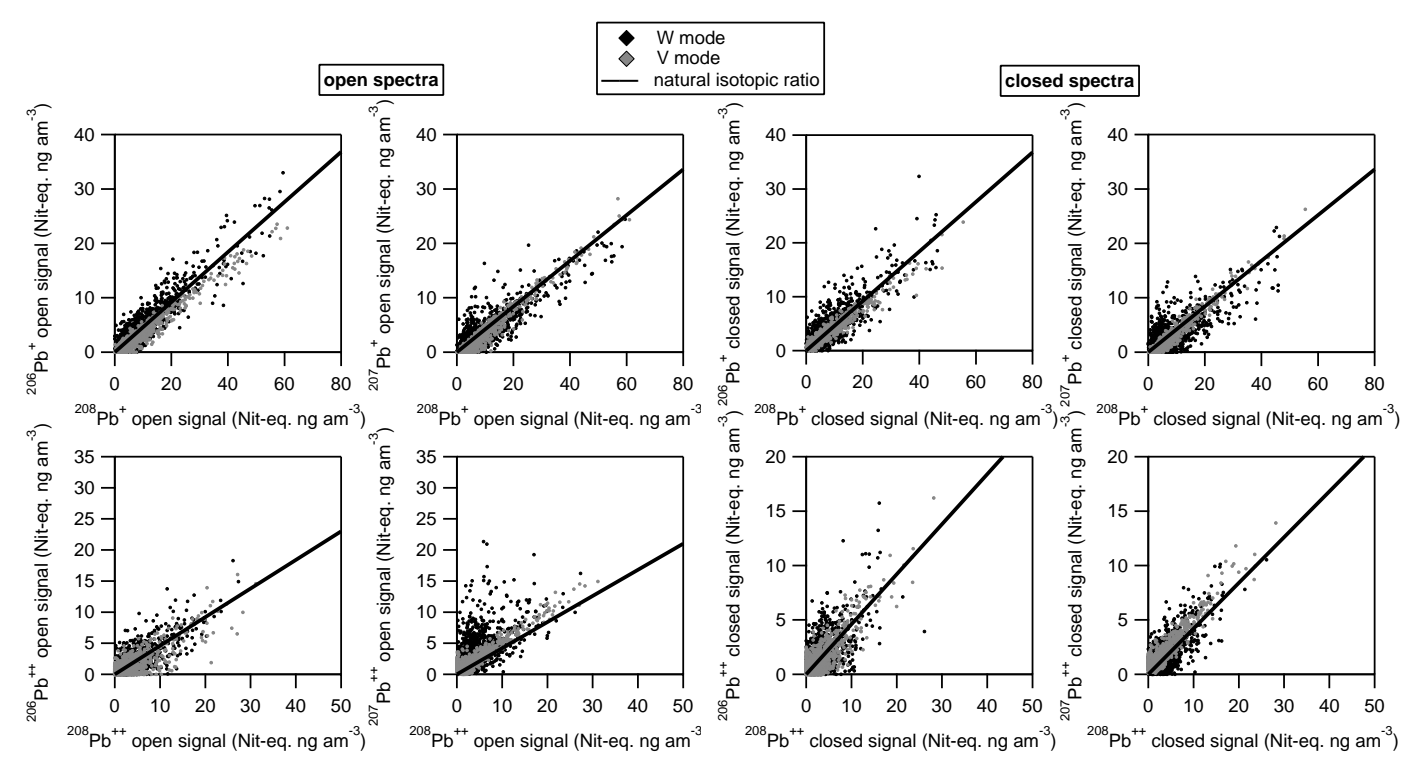

Fig. 3. Scatter plots of lead isotopic ion signals obtained with the HR-AMS located at T0. V and W mode data for open and closed spectra are shown. Black lines correspond to the expected isotopic ratio (deLaeter et al., 2003). The top panels show the singly charged ions and the bottom panels show the doubly charged ions.

same for $\mathrm{V}$ - and $\mathrm{W}$ - modes. The variations observed are a reflection of the uncertainties in the ion signal caused by uncertainty in the results of the fitting routine given the presence of noise and partially interfering ions, specially for $\mathrm{V}$ mode, where the resolution is lowest.

The relatively high correlation between the signals of the six ions discussed, together with the isotopic ratios, confirm their identity as lead ions. Hence, total $\mathrm{Pb}$ open and closed signals were calculated as the sum of the ${ }^{208} \mathrm{~Pb}^{+},{ }^{207} \mathrm{~Pb}^{+}$, ${ }^{206} \mathrm{~Pb}^{+},{ }^{208} \mathrm{~Pb}^{++},{ }^{207} \mathrm{~Pb}^{++}$and ${ }^{206} \mathrm{~Pb}^{++}$signals. The measured signal of ${ }^{207} \mathrm{~Pb}^{++}$was not used for the open W-mode due to its poor accuracy and was estimated instead from the ${ }^{208} \mathrm{~Pb}^{++}$signal and the expected isotopic ratio. Data were averaged for consecutive $\mathrm{V}$ - and $\mathrm{W}$ - mode runs, producing a base time series with one 10-minute averaged data point every 20 minutes which is used in the remainder of this paper.
Figure 4 shows raw mass spectra from the C-AMS at $m / z$ 200-215 for two different periods with high and low $\mathrm{Pb}$ signals. The open signals during the high $\mathrm{Pb}$ event show the expected isotopic ratio, while the open signals for the low $\mathrm{Pb}$ event show more 207 relative to 206 and 208. This indicates a non-lead ion at 207 that interferes with detection of the ${ }^{207} \mathrm{~Pb}$, which is consistent with the patterns observed for the HR-AMS data in Fig. S2. In order to quantify the contribution of lead ions to the signal at $\mathrm{m} / \mathrm{z}, 204,206,207$, and 208, the unit mass resolution C-AMS data requires a fragmentation table (Allan et al., 2004; Canagaratna et al., 2007), shown in Table 2. Analogously to the PAH quantification method of Dzepina et al. (2007), the organic signal in $\mathrm{m} / \mathrm{z}, 206$ and 208 was estimated from the signals at 205 and 209-210, respectively, which are assumed to be due to organic ions. The rest of the signal at $\mathrm{m} / \mathrm{z} 206$ and 208 
Table 2. Fragmentation table used to determine the $\mathrm{Pb}$ signal at $\mathrm{m} / \mathrm{z}, 204,206,207$, and 208 from the C-AMS data.

\begin{tabular}{lll}
\hline$m / z$ & frag_organic & frag_Pb \\
\hline 204 & $204,-$ frag_Pb[204] & $0.0267 \times$ frag_Pb[208] \\
205 & 205 & \\
206 & frag_organic[205] & $206,-$ frag_organic[206] \\
207 & $207,-$ frag_Pb[207] & $0.422 \times$ frag_Pb[208] \\
208 & $0.5 \times$ frag_organic[209], & $208,-$ frag_organic[208] \\
& $0.5 \times$ frag_organic[210] & \\
209 & 209 & \\
210 & 210 & \\
\hline
\end{tabular}

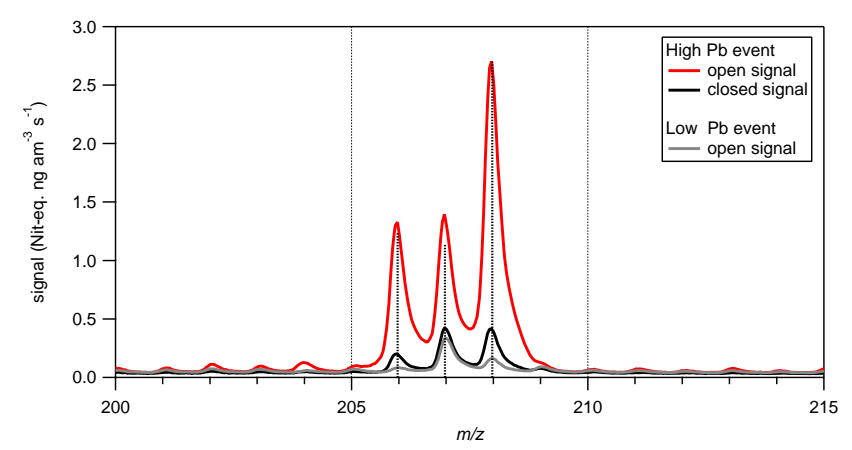

Fig. 4. 1 min averaged open and closed raw spectra from the CAMS for a high and a low $\mathrm{Pb}$ event. The position of the dashed vertical lines indicate the exact mass of the ${ }^{206} \mathrm{~Pb},{ }^{207} \mathrm{~Pb}$, and ${ }^{208} \mathrm{~Pb}$ and their height, the relative abundance of the three $\mathrm{Pb}$ isotopes.

is assigned to ${ }^{206} \mathrm{~Pb}^{+}$and ${ }^{208} \mathrm{~Pb}^{+}$, respectively. Because of the small abundance of ${ }^{204} \mathrm{~Pb}$ and the large interference for ${ }^{207} \mathrm{~Pb}$, lead signals at $\mathrm{m} / \mathrm{z} 204$ and 207 were estimated from ${ }^{208} \mathrm{~Pb}^{+}$and the natural relative abundance of the isotopes. A good correlation between ${ }^{206} \mathrm{~Pb}^{+}$and ${ }^{208} \mathrm{~Pb}^{+}$as well as between background-corrected ${ }^{207} \mathrm{~Pb}^{+}$and ${ }^{208} \mathrm{~Pb}^{+}$, with the expected isotopic ratio (see Table 1 and Fig. 5), unequivocally confirms the identification of particulate lead signals measured with the C-AMS.

\subsection{Lead evaporation}

Figure 6 compares the time series of the open and closed total $\mathrm{Pb}$ signals at $\mathrm{T} 0$. In general, the closed signal represents the instrument background signal. Since there are no sources of $\mathrm{Pb}$ inside of the AMS, the relatively large and time-varying closed signal is most likely generated by residual lead that remains on the vaporizer due to the relatively low volatility of the lead compounds. In order to describe this effect, a model was developed to estimate the input $\mathrm{Pb}$ signal into the AMS from the observed open and closed signals. The model is described in detail in Appendix A, and a diagram of the model is shown in Fig. 7. In the model, an incoming aerosol $\mathrm{Pb}$

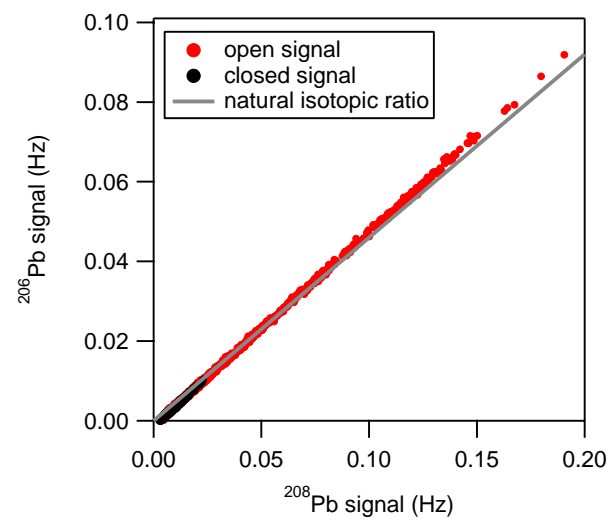

Fig. 5. Scatter plots of ${ }^{206} \mathrm{~Pb}^{+}$vs. ${ }^{208} \mathrm{~Pb}^{+}$signals from the C-AMS. Black line corresponds to the expected isotopic ratio (deLaeter et al., 2003).

mass concentration ("input" signal) is modulated by a device that blocks or transmits the aerosol beam before it reaches the vaporizer. As the particles impact on the vaporizer, it is assumed that the particles are lodged on the porous tungsten vaporizer, and then the $\mathrm{Pb}$-containing molecules desorb from the vaporizer as a first-order process (exponential decay). If the desorption rate is much faster than the open/close alternation time of the blocking device, the observed closed signal will be small or negligible. However, if the aerosol component desorbs slowly, a larger closed signal will be observed. In the limit of a very slowly evaporating species (with a timescale of evaporation much longer than the open/closed alternation time), the open signal will equal the closed signal.

The model was used to estimate the $\mathrm{Pb}$ "input" signal (i.e. ambient $\mathrm{PM}_{1} \mathrm{~Pb}$ sampled by the AMS) from the observed open signal, by minimizing the sum of squared differences between modeled and observed closed signals $\left(\chi^{2}\right)$. A better description of the data was obtained by assuming two fractions that desorb fast and slowly, respectively, from the vaporizer. We estimated that $\sim 25 \%$ of the aerosol $\mathrm{Pb}$ that impacts the vaporizer evaporates rapidly with an exponential decay constant larger than $10 \mathrm{~s}^{-1}$ (1/e decay time, $\tau<0.1 \mathrm{~s}$ ) and the rest evaporates more slowly with a decay constant of $\sim 0.007 \mathrm{~s}^{1}(\tau \sim 2.4 \mathrm{~min})$. Given its rapid decay time, the fast-evaporating fraction would not be expected to generate a closed signal. As discussed below, the two fractions may correspond to different chemical forms of the $\mathrm{Pb}$ with different vapor pressures.

The concentrator periods allowed us to look more closely into the effect of slow vaporizing compounds because they serve as spikes of the lead input into the AMS and it is possible to investigate their effect in subsequent time periods. For example, for $2.5 \mathrm{~min}$ averaged data, it is observed that after a concentrator period followed by an ambient period, the signal of the first ambient data point is always larger than the next one, even within the noise (see Fig. S5). This is 


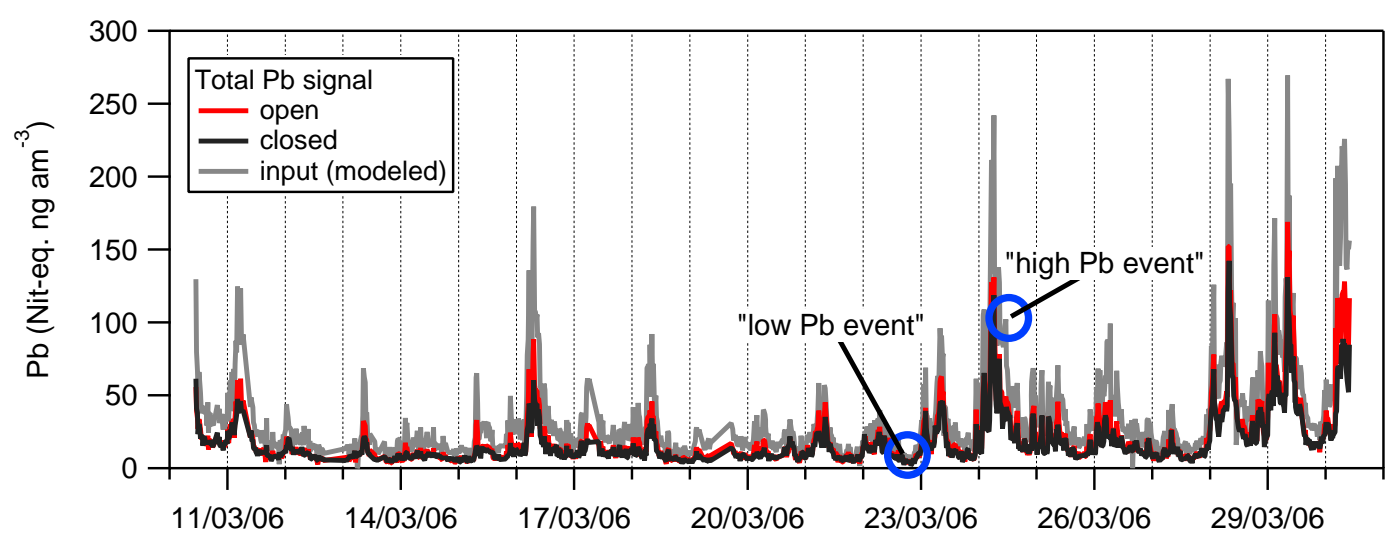

Fig. 6. Time series of open (red line), closed (black line) and calculated total input (grey line) Pb signal for the HR-AMS at T0. Circled periods in blue, correspond to low and high $\mathrm{Pb}$ events in Fig. 2.

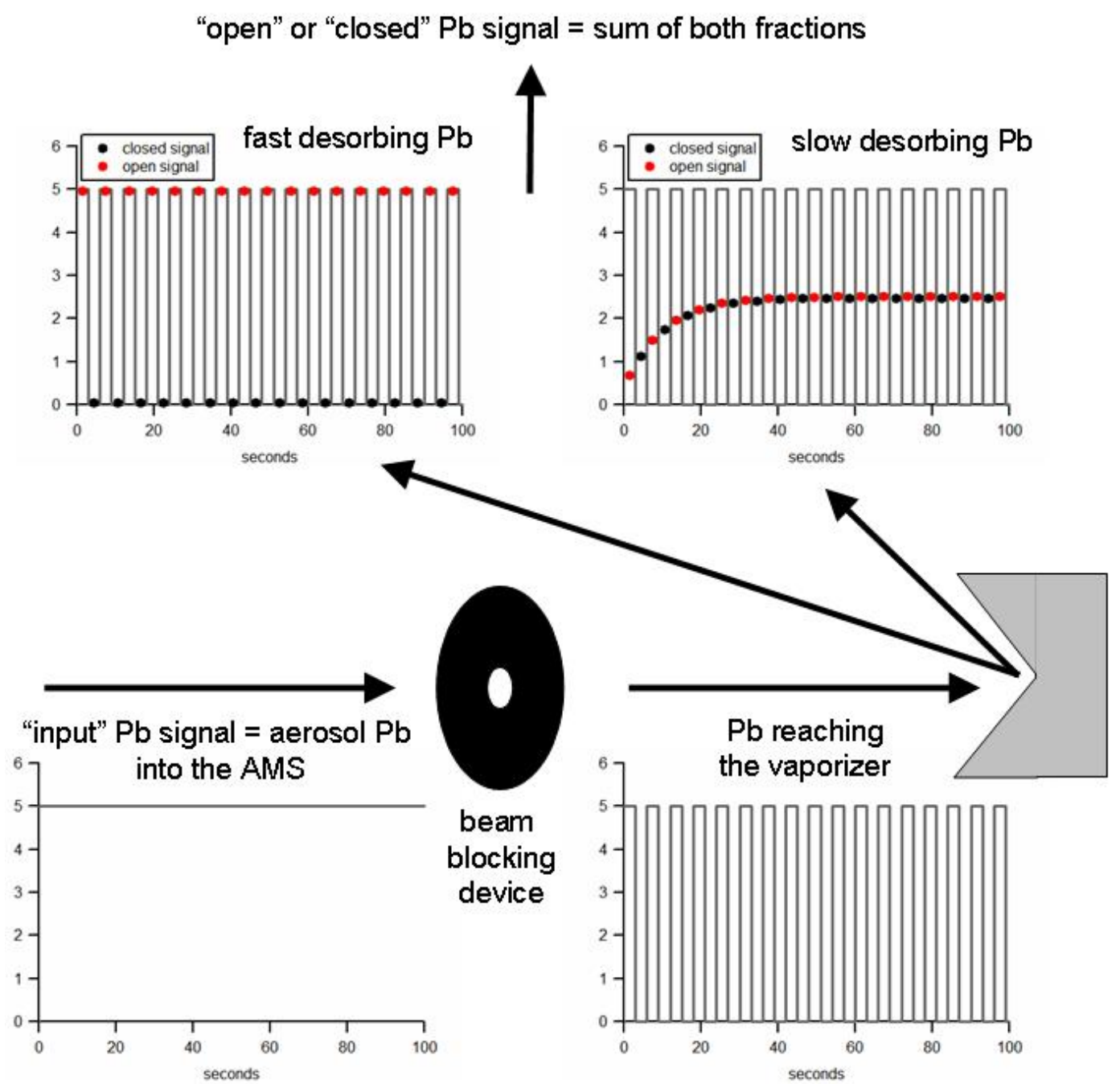

Fig. 7. Diagram of the adsorption/desorption model used to calculate the "input" total $\mathrm{Pb}$ signal. Given a constant input of $5 \mu \mathrm{g} / \mathrm{m}^{3}$ (lower left), the beam blocking device modulates the incoming signal (lower right). For fast desorbing Pb components, this modulation fully separates the "open" signal from a "closed" background (upper left). For the slow desorbing Pb components, the detection of the sampled $\mathrm{Pb}$ is nearly independent of the modulation (upper right) and the total measured signal is the sum of the "open" and "closed" fractions. 


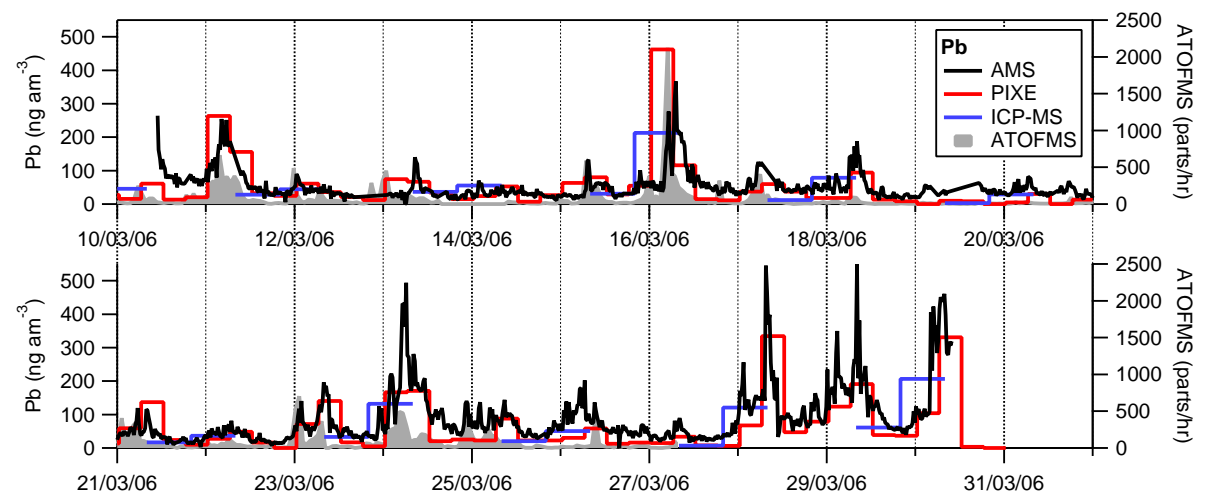

Fig. 8. Time series of Pb measurements at T0: HR-AMS (black line), PIXE (red bars; Moffet et al., 2008a), and ICP-MS (blue bars; Moreno et al., 2008; Querol et al., 2008) mass concentrations, and ATOFMS signals in particle counts per hour (grey filled area) (Moffet et al., 2008a, b).

consistent with a decay time of $2.4 \mathrm{~min}$. If the decay time were larger than the averaging period, the effect of the input spike would be noticeable many data points after it; if it were smaller, the signals after the input spike would have a random relative magnitude.

\subsection{Lead signal calibration}

The AMS technique has been typically considered to be limited to the detection of chemical species that vaporize rapidly (much faster than the typical beam open/closed alternation time of $3-5 \mathrm{~s})$ at the temperature of the vaporizer $\left(\sim 600^{\circ} \mathrm{C}\right)$ (Jayne et al., 2000; Jimenez et al., 2003; Canagaratna et al., 2007). For example, highly refractory material such as crustal material and elemental carbon or soot have not been observed to produce a measurable signal within an AMS. Other species considered "refractory" for AMS detection, such as sodium chloride, potentially provide a slowly evaporating signal, but this has not been studied in detail to our knowledge. The present paper represents the first attempt to quantify the particulate mass concentration of chemical species that evaporate from the vaporizer on slower time scales than non-refractory material but still within a time constant of the order of seconds to minutes.

In order to calculate $\mathrm{Pb}$ mass concentration from the AMS measurements, it is necessary to know the ionization efficiency of lead relative to nitrate $\left(\mathrm{RIE}_{\mathrm{Pb}}\right)$ (Jimenez et al., 2003; Canagaratna et al., 2007):

$C_{\mathrm{Pb}}=\frac{C_{\mathrm{Pb}, \text { Nit.eq. }}}{\mathrm{RIE}_{\mathrm{Pb}}}$

where $C_{\mathrm{Pb}}$ is the lead concentration in $\mathrm{ng} \mathrm{m}^{-3}$ and $C_{\mathrm{Pb} \text {,Nit.eq. }}$ is the lead concentration in Nitr.-eq. $\mathrm{ng} \mathrm{m}^{-3}$. Laboratory experiments were performed with pure $\mathrm{Pb}\left(\mathrm{NO}_{3}\right)_{2}$ particles in order to determine $\mathrm{RIE}_{\mathrm{Pb}}$. In these experiments, the total number of $\mathrm{Pb}$ ions (including singly and doubly charged) was compared to the total number of nitrate ions measured from size-selected $\mathrm{Pb}\left(\mathrm{NO}_{3}\right)_{2}$ particles. With this technique, the $\mathrm{RIE}_{\mathrm{Pb}}$ can be measured without needing to separately measure the collection efficiency (CE) of the particles because it compares two ions coming from the same molecule. Experiments were performed on several different HR-AMS instruments, as well as with a quadrupole AMS, and at several different vaporizer temperatures $\left(550-750^{\circ} \mathrm{C}\right)$. At lower vaporizer temperatures, substantial amounts of $\mathrm{Pb}$ were observed in the closed signals, similar to the field data (see Fig. S6, panel b). Applying the model described in Sect. 3.2 to the observed signals, we determined that $\mathrm{RIE}_{\mathrm{Pb}}$ was $0.5 \pm 0.3$. This is in reasonable agreement with an estimate of $\mathrm{RIE}_{\mathrm{Pb}}$ of 0.37 derived from the ionization cross-section of $\mathrm{Pb}$ by $70 \mathrm{eV}$ electrons $\left(0.28 \mathrm{~A}^{2}\right)$ (McCartney et al., 1998; Jimenez et al., 2003). A RIE $<1$ is expected for heavy atoms such as $\mathrm{Pb}$, as the inner electrons are more strongly bound to the nucleus and thus have a lower probability of ejection upon interaction with the incoming $70 \mathrm{eV}$ electron.

Using the "input" $\mathrm{Pb}$ signal (in Nitr.-eq. $\mathrm{ng} \mathrm{am}^{-3}$ ) derived from the model fits to the ambient data (corrected for CE) in Sect. 3.2 and $\mathrm{RIE}_{\mathrm{Pb}}=0.5$, we calculated the time series of AMS submicron $\mathrm{Pb}$ mass concentration (in $\mathrm{ng} \mathrm{am}^{-3}$ ) at $\mathrm{T} 0$ from Eq. (1).

\subsection{AMS vs. other $\mathrm{Pb}$ measurements at $\mathrm{TO}$}

The time series of $\mathrm{Pb}$ mass concentration at $\mathrm{T} 0$ is compared to other $\mathrm{Pb}$ measurements at the same site in Figs. 8 and 9. Figure 8 shows the time series of $\mathrm{Pb}$ determined with AMS, PIXE, ICP-MS and ATOFMS. Note the different particle size for the different measurements $\left(\mathrm{PM}_{1}, 0.07-1.15 \mu \mathrm{m}, \mathrm{PM}_{2.5}\right.$, and $0.2-2 \mu \mathrm{m}$ for AMS, PIXE, ICP-MS and ATOFMS, respectively). The ATOFMS reports particle counts and, hence, it is plotted on a different axis than the rest of the measurements. Figure 9 shows scatter plots between all the instruments. Due to the fact that PIXE and ICP-MS report concentrations in 6 and $12 \mathrm{~h}$ time periods, respectively, we 

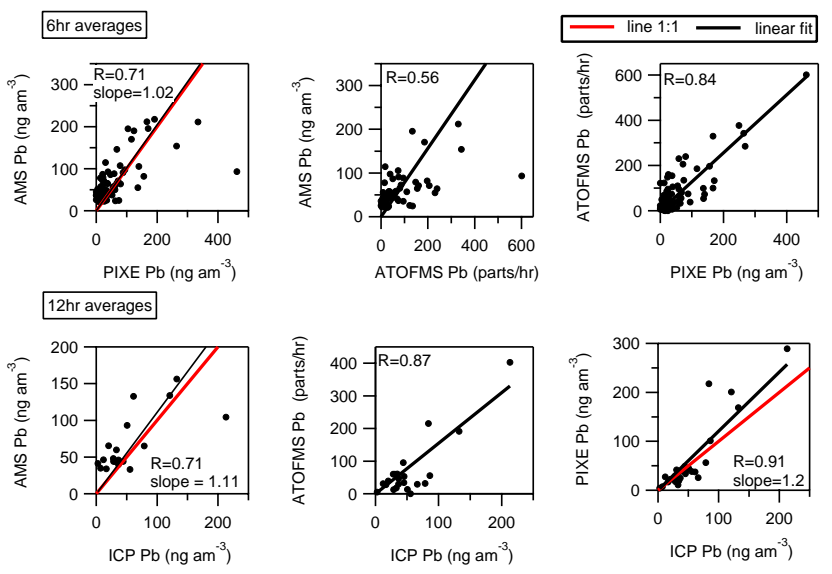

Fig. 9. Scatter plots and linear fits comparing the different $\mathrm{Pb}$ mass measurements at T0. Data was remapped into PIXE and ICP-MS time series ( 6 and $12 \mathrm{~h}$ averages, respectively) for proper comparisons. 1:1 and regression lines and regression slope values are shown where relevant.

remapped the time series of the other instruments to the PIXE and ICP-MS time grids. The four methods exhibit similar time trends, such as high levels of $\mathrm{Pb}$ peaking at $\sim 200$ $500 \mathrm{ng} \mathrm{am}^{-3}$ on 11, 16, 24, and 28-30 March, and low levels of $\mathrm{Pb}$ (below $100 \mathrm{ng} \mathrm{am}^{-3}$ for $12+\mathrm{h}$ averages) during 12-15 and 17-20 March. Figure 9 shows correlation between all the measurements although with substantial scatter in all cases, which may be partially due to noise in the different methods as well as the differences in size cuts. The slopes of the fit line of HR-AMS vs. PIXE and ICP-MS are close to 1, indicating good agreement between the three instruments and supporting the value of $\mathrm{CE}$ used for $\mathrm{Pb}$.

\section{5 $\mathrm{Pb}$ data obtained with the aerosol concentrator at T0}

As discussed above, particle $\mathrm{Pb}$ has been reported as $\mathrm{PbS}$, $\mathrm{PbCl}_{2}, \mathrm{PbSO}_{4}, \mathrm{PbO}, \mathrm{PbCO}_{3}, \mathrm{PbNO}_{3}$ and $\mathrm{PbSe}$. We did not observe signals above the noise corresponding to ions of any of these compounds in ambient spectra $\left(\mathrm{PbS}^{+}, \mathrm{PbCl}_{2}^{+}\right.$, $\mathrm{PbCl}^{+}, \mathrm{PbSO}_{4}^{+}, \mathrm{PbO}^{+}, \mathrm{PbCO}_{3}^{+}, \mathrm{PbNO}_{3}^{+}, \mathrm{PbNO}_{2}^{+}, \mathrm{PbNO}^{+}$, and $\left.\mathrm{PbSe}^{+}\right)$. However, during the periods that the AMS was sampling through the aerosol concentrator, we identified signals of ions with the exact mass of $\mathrm{PbS}^{+}$and $\mathrm{PbCl}^{+}$, in addition to the singly and doubly charged $\mathrm{Pb}$ ions in $\mathrm{V}$ - and W-mode spectra (see Figs. S7 and S8), while signals for the rest of the ions listed above were not observed. Open and closed signals were observed for $\mathrm{PbS}^{+}$and $\mathrm{PbCl}^{+}$, however, closed signals of $\mathrm{PbCl}^{+}$were very low. Scatter plots of the ${ }^{207} \mathrm{~Pb}$ and ${ }^{206} \mathrm{~Pb}$ vs. ${ }^{208} \mathrm{~Pb}$ sulfide and chloride ions show that they have the expected isotopic ratio for $\mathrm{Pb}$ and $\mathrm{Cl}$ isotopes (see Fig. S9).
In Fig. 10a, the time series of the HR-AMS open signal for ${ }^{208} \mathrm{~Pb}^{+}$when sampling through the concentrator is compared to the ambient ${ }^{208} \mathrm{~Pb}^{+}$open signal (when sampling ambient air without the concentrator), showing a good correlation and corroborating that the use of the concentrator does not distort the lead signals. The open and closed signals of ${ }^{208} \mathrm{PbS}^{+}$, ${ }^{208} \mathrm{PbCl}^{+}$when sampling through the concentrator are shown in Fig. 10b-c. The high closed/open signal ratio for $\mathrm{PbS}^{+}$, compared to the much lower value for $\mathrm{PbCl}^{+}$, is a reflection of the higher volatility of the species producing the $\mathrm{PbCl}^{+}$ ions compared to those producing $\mathrm{PbS}^{+}$. For reference, $\mathrm{PbS}$ has melting and boiling points of $1114^{\circ} \mathrm{C}$ and $1281^{\circ} \mathrm{C}$, respectively, and $\mathrm{PbSO}_{4}$ has a melting point of $1170^{\circ} \mathrm{C}$ (no boiling point data is available for $\mathrm{PbSO}_{4}$ ); while $\mathrm{PbCl}_{2}$ has melting and boiling points of $934^{\circ} \mathrm{C}$ and $1742^{\circ} \mathrm{C}$, respectively (NOAA, 2009). Thus no obvious relationship is apparent between the melting and boiling points of these compounds and the observed evaporation rates in the AMS.

It is also interesting to note that, although the times series of $\mathrm{PbCl}^{+}$and $\mathrm{PbS}^{+}$are similar, they are not identical; the differences are probably caused by particles with different lead composition depending on their source. The observation of different evaporation properties of the species that give rise to $\mathrm{PbS}^{+}$and $\mathrm{PbCl}^{+}$is interesting because it is consistent with the evaporation model results that suggested the existence of two lead fractions with different volatilities. However, it is not possible to directly identify the two fractions of the model with specific sources of $\mathrm{PbCl}^{+}$and $\mathrm{PbS}^{+}$ions because there may be other $\mathrm{Pb}$ species in the aerosol. To further explore this point we attempted to reconstruct the total $\mathrm{Pb}^{+}$signal using a linear combination of the $\mathrm{PbCl}^{+}$and $\mathrm{PbS}^{+}$signals:

$S_{\mathrm{Pb}+}=a S_{\mathrm{PbS}+}+b S_{\mathrm{PbCl}+}$

where $S_{i}$ corresponds to the open signal of ion $i$, while sampling through the concentrator. A fit of the field data to Eq. (2) was performed with the built-in fitting routines included in the Igor Pro 6.05 data analysis software (WaveMetrics, 2008). The fit yields values of 7.2 and 6.2 for coefficients $a$ and $b$, respectively (see Fig. S10). The relative residual - (fit - field data)/field data - of the fit is highly variable with values from -2.5 to 1 and an average of 0.2 . This result implies that lead species that generate $\mathrm{PbCl}^{+}$and $\mathrm{PbS}^{+}$ ions (and/or species that are co-emitted with those), account for most, but not all of the variability of the $\mathrm{Pb}$ during this period.

\subsection{Locations of particulate lead sources impacting the T0 site}

Figure 11 shows the time series and the diurnal cycle of the submicron $\mathrm{Pb}$ mass concentration at T0. Periods of elevated $\mathrm{Pb}$ can be seen in the early morning with maximum average concentrations around $7 \mathrm{am}$; in contrast, concentrations remain low in the afternoon and night. A slight decrease in lead concentrations was observed during weekends and the 


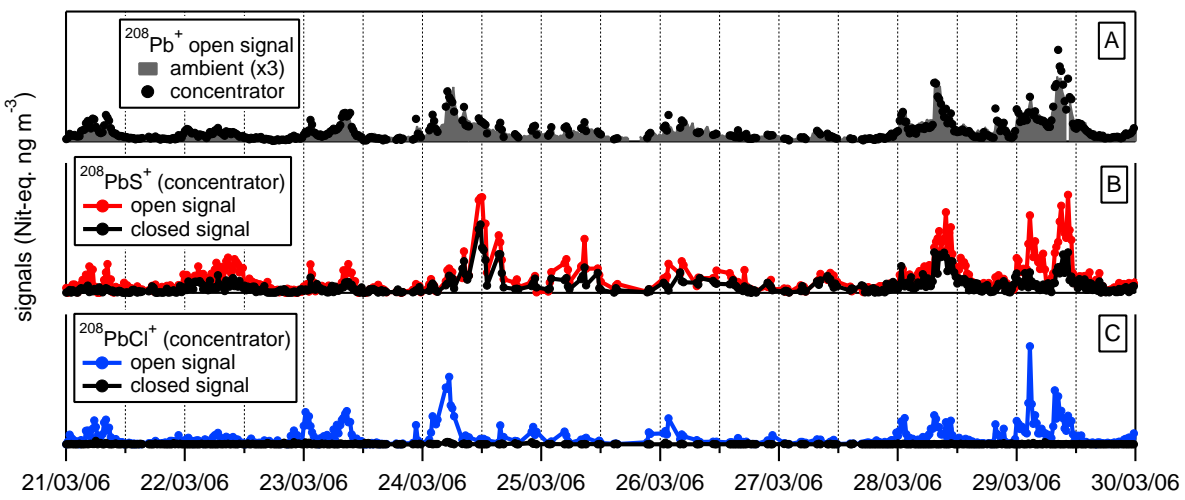

Fig. 10. Panel (A): Time series of ${ }^{208} \mathrm{~Pb}^{+}$ambient and concentrator open signals. Note that ambient signal has been multiplied by 3 . Panels (B) and (C): Time series of concentrator ${ }^{208} \mathrm{PbS}^{+}$and ${ }^{208} \mathrm{PbCl}^{+}$, respectively, open and closed ions signals. All data collected at T0.
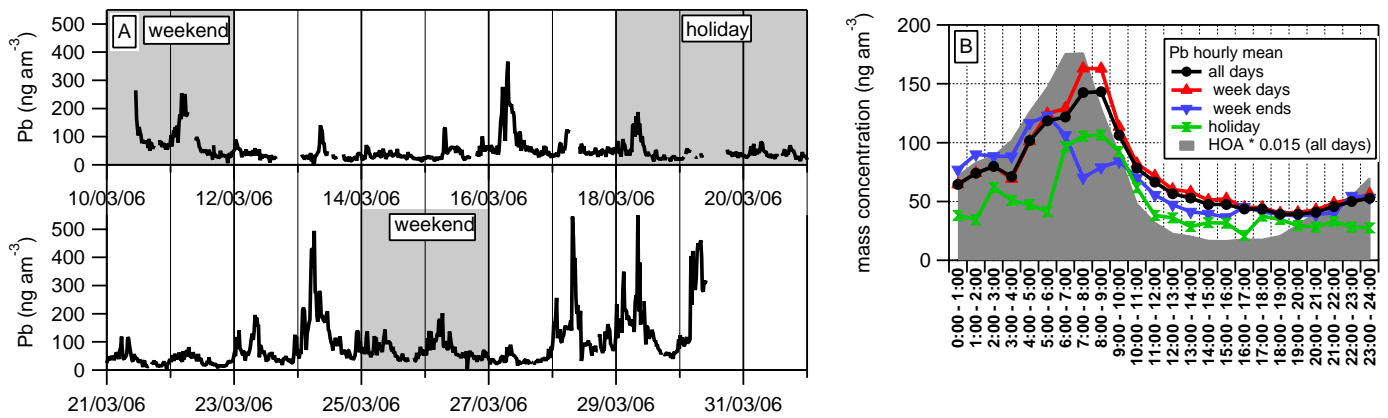

Fig. 11. Panel (A): Time series of $\mathrm{Pb}$ mass concentration at $\mathrm{T} 0$ showing weekend and holiday periods during the measurement. Panel (B): Diurnal cycle of total $\mathrm{Pb}$ mass concentration for all days, week day, weekends and holidays, compared to the PMF AMS factor, HOA (Aiken et al., 2009) which is a marker for primary organic aerosol.

long holiday weekend from 18 to 20 April, consistent with industrial sources. In general, the shape of the diurnal cycle of $\mathrm{Pb}$ is consistent with urban emissions during the night and early morning into a shallow boundary layer (BL) with weak drainage flows into the basin (deFoy et al., 2008). During the late morning and afternoon, the BL height increases greatly as the ground warms up due to solar radiation (Shaw et al., 2007), resulting in lower concentrations of primary urban species. Very similar diurnal cycles have been observed in Mexico City for other urban primary species such as PAHs (Dzepina et al., 2007), hydrocarbon-like organic aerosol (also shown in Fig. 11) (Aiken et al., 2009), and black carbon (Paredes-Miranda et al., 2009).

Figure 12 shows a comparison of the ambient particle $\mathrm{Pb}$ time series for different periods with time series of other potentially-related particle components such as chloride, and two components of the organic aerosol fraction determined by Aiken et al. (2009) from positive matrix factorization analysis (PMF; Ulbrich et al., 2009) of HR-AMS spectra. The two PMF components correspond to chemicallyreduced urban primary emissions (hydrocarbon-like organic aerosol, HOA) and a local primary nitrogen-containing organic aerosol (LOA). Signals for open $\mathrm{PbCl}^{+}$and $\mathrm{PbS}^{+}$ during concentrator periods are also shown. Additionally, we show HR-AMS open ${ }^{64} \mathrm{Zn}^{+}$signal because $\mathrm{Pb}$ has been reported to be internally mixed with $\mathrm{Zn}$ in Mexico City particles (Moffet et al., 2008a). Comparison of $\mathrm{Pb}$ with other aerosol components (sulfate, nitrate, black carbon, BBOA, OOA) and gases $\left(\mathrm{CO}\right.$ and $\left.\mathrm{SO}_{2}\right)$ did not show any relevant correlation, even for short plumes, and hence are not shown. In particular, a close analysis of the wind patterns and time series of $\mathrm{Pb}$ and $\mathrm{SO}_{2}$ plumes from Tula (deFoy et al., 2009b) observed suggests that $\mathrm{Pb}$ plumes do not have their origin at the refinery. Figure 12 shows four different time periods in which $\mathrm{Pb}$ plumes were observed. $\mathrm{Zn}$ shows good correlation with $\mathrm{Pb}$ for all four periods, consistent with the association reported by Moffet et al. (2008a). AMS NR-chloride, which is thought to be dominated by $\mathrm{NH}_{4} \mathrm{Cl}$ in Mexico City (Salcedo et al., 2006; Johnson et al., 2008) shows some correlation with $\mathrm{Pb}$ or $\mathrm{PbCl}^{+}$but less than with $\mathrm{Zn}^{+}$, suggesting that the sources of the majority of the submicron non-refractory chloride are partially disjoint from those of lead or lead chlorides. The closed signal of the AMS chloride, which was found to be substantial (Huffman et al., 2009), does not show a better correlation with $\mathrm{Pb}$. Finally, HOA and LOA also show variable correlation, although some $\mathrm{Pb}$ plumes appear 


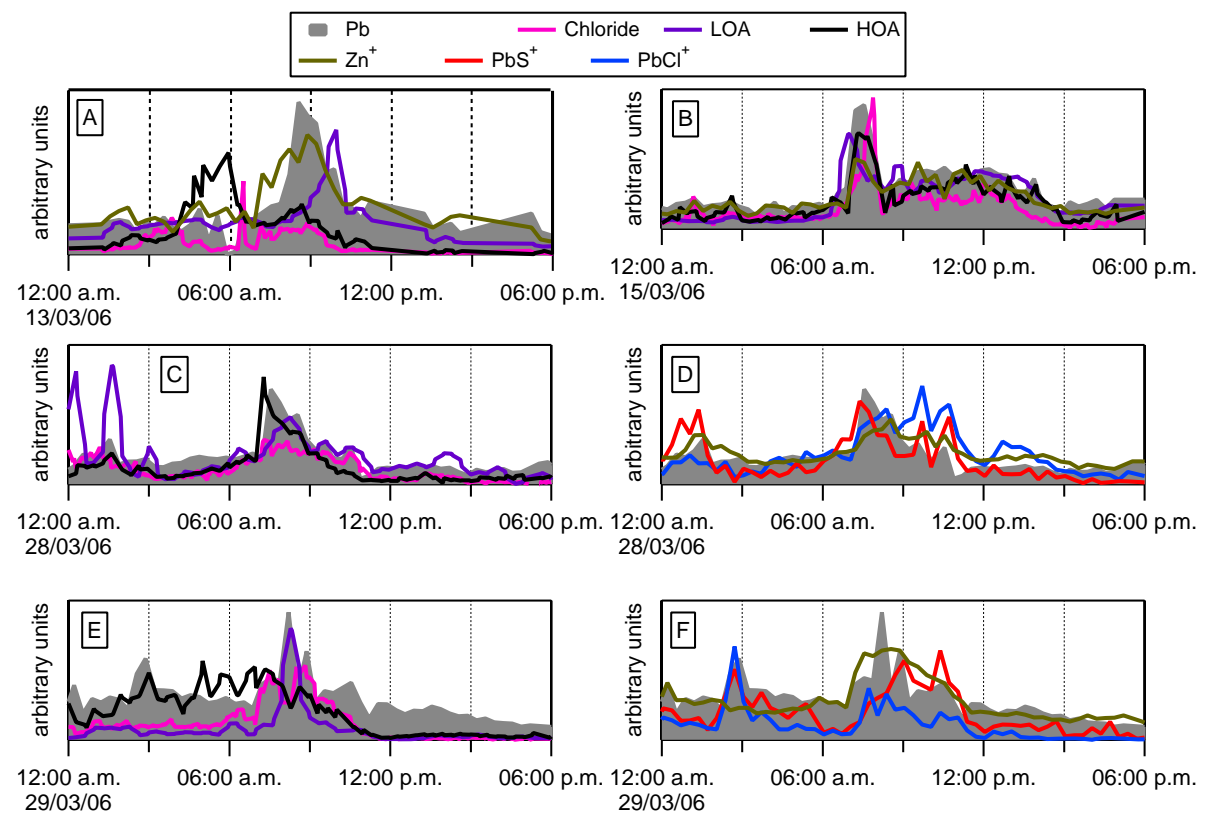

Fig. 12. Time series of aerosol components: $\mathrm{Pb}$ mass concentration, ${ }^{64} \mathrm{Zn}^{+},{ }^{208} \mathrm{PbS}^{+}$and,${ }^{208} \mathrm{PbCl}^{+}$open signals (this work) and chloride, HOA, and LOA mass concentration from Aiken et al. (2009) on four different days at T0. LOA and HOA are AMS-PMF factors corresponding to hydrocarbon-like organic aerosol and a local primary nitrogen-containing organic aerosol, respectively. Panels (A) and (B) show time series on 13 and 15 March, respectively; no concentrator data $\left(\mathrm{PbS}^{+}\right.$and $\left.\mathrm{PbCl}^{+}\right)$is available for those days. Panels $(\mathbf{C})$ and $(\mathbf{D})$ show data on 28 March and panels (E) and (F) show 29 March data.

to be accompanied by HOA and/or LOA plumes, perhaps due to industrial combustion emissions which may be coemitted or emitted nearby the $\mathrm{Pb}$ sources.

In order to explore the potential source regions for the particulate $\mathrm{Pb}$ which reaches $\mathrm{T} 0$, "Concentration Field Analysis" (CFA; Seibert et al., 1994; deFoy et al., 2007) was carried out using the HR-AMS Pb data set. Stochastic particle trajectories were calculated using WRF-FLEXPART (Stohl et al., 2005; Doran et al., 2008). Wind fields for the trajectories were simulated using the Weather Research and Forecast model (WRF; Skamarock et al., 2005) and were evaluated using a combination of statistical metrics, cluster analysis and CFA (deFoy et al., 2009a). The analysis time period was limited to 11-26 March inclusive, as the period after 26 March had highly variable winds due the passage of convective cells, which are not captured accurately by the model and thus reduce the ability of the model to adequately represent wind transport. Results from several previous studies during MILAGRO support the ability of FLEXPART to accurately predict the dispersion of emissions in the MCMA region (Aiken et al., 2010; Rivera et al., 2009; DeCarlo et al., 2010). CFA results for $\mathrm{Pb}$ mass concentration at $\mathrm{T} 0$ are shown in Panel A of Fig. 13 suggesting potential source regions to the south/southwest of T0. Weaker source regions appear east of Texcoco and north of T0 towards Tula.

The CFA technique was previously applied to ATOFMS data at T0 during MILAGRO (Moffet et al., 2008b). The results for particles containing $\mathrm{NaClZnPb}$ suggested a source northwest of T0, in contrast with the present work (see Fig. $9 \mathrm{~b}$ in that paper). The main difference is due to an updated version of the YSU boundary layer scheme (Hong et al., 2006) in WRF version 3.1, whereas version 2.2 was used in (Moffet et al., 2008b). Because the CFA signature of $\mathrm{NaClZnPb}$ particles was the result of a few early morning peaks, it is particularly sensitive to changes in the simulation of the night time boundary layer. Repeating the analysis for the ATOFMS data yields similar results as Fig. 13 in this paper, but does not change substantially the other figures in that paper as the other species were less sensitive to the specific model changes.

Because of the sensitivity of the CFA results for this case, the analysis was supplemented using vertical wind profiles. A radar wind profiler (RWP, $915 \mathrm{MHz}$ model manufactured by Vaisala) was installed at T0 and operated in a 5-beam mode with nominal 192-m range gates. As described in Doran et al. (2007), the NCAR Improved Moment Algorithm was used to obtain 30-min average consensus winds. Figure 14 shows the wind rose for AMS Pb using the RWP data up to $500 \mathrm{~m}$ of the boundary layer at $\mathrm{T} 0$. High $\mathrm{Pb}$ events are clearly associated with wind transport from the south and to a lesser extent from the north, in agreement with CFA results.

Similar CFA and RWP analyses were applied to $\mathrm{PbS}^{+}$ and $\mathrm{PbCl}^{+}$time series. The results for CFA are shown in Fig. 13 panels $b$ and $c$ and show that there is a very probable 

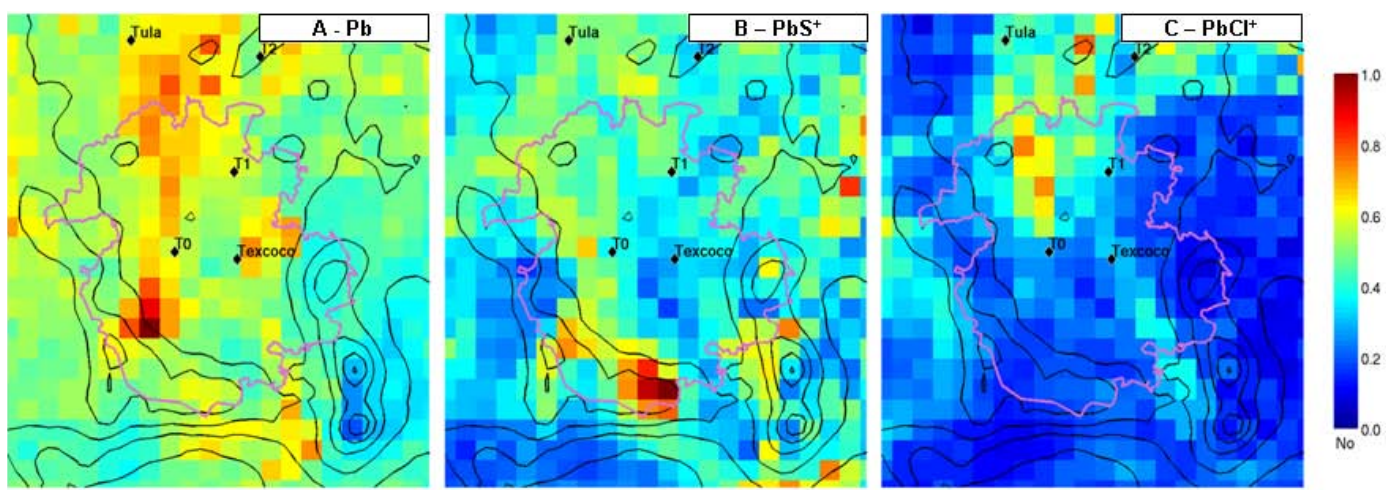

Fig. 13. Concentration Field Analysis (CFA) results for AMS Pb mass concentration - Panel (A), and ${ }^{208} \mathrm{PbS}^{+}-\mathrm{Panel}_{(\mathbf{B}) \text { and }}{ }^{208} \mathrm{PbCl}{ }^{+}$ (Panel C) open signals at T0. The color scale is proportional to the probability of the presence of a source region of $\mathrm{Pb}$ at each location. The pink line corresponds to the limits of the Mexico City Metropolitan Area, black terrain contour lines shown every $500 \mathrm{~m}$.

source of compounds generating $\mathrm{PbS}^{+}$in the south, whereas $\mathrm{PbCl}^{+}$has a strong northerly origin. On the other hand, the wind roses are similar for both ions, and indicate southerly winds when concentrations are higher (see Fig. S11). This is because the CFA method uses more complete information (back-trajectories calculated from three-dimensional WRF wind fields) and is more influenced by some large peaks, vs. than the RWP method which only uses the winds at T0 and is more sensitive to the median. These results are consistent with our previous conclusion that $\mathrm{PbS}^{+}$and $\mathrm{PbCl}^{+}$ signals are caused by particles with different lead composition depending on their source. The CFA plots for $\mathrm{PbS}^{+}$and $\mathrm{PbCl}^{+}$do not account for all the possible sources that the CFA shows for total $\mathrm{Pb}$. For example, Fig. 13 shows a $\mathrm{Pb}$ source east of the city, indicating that there might be other $\mathrm{Pb}$ compounds that contribute to the total $\mathrm{Pb}$ signal in addition to those compounds generating $\mathrm{PbS}^{+}$and $\mathrm{PbCl}^{+}$signals in the AMS.

\subsection{Particle lead at PEMEX site}

The Aerodyne Mobile Laboratory, equipped with a C-AMS, made multiple day measurements at 6 sites in the MCMA during the MILAGRO study, including the T0 supersite (ground level) and the PEMEX site. The mass spectral data from the C-AMS were analyzed for particulate lead signals for the full study; however, the positively identifiable particulate lead signals were only observed during measurements at the PEMEX site.

Figure 15, top panel shows the time series of the C-AMS particulate open and closed $\mathrm{Pb}$ signals. The particulate lead signals measured at the PEMEX site from the afternoon of 26 March to midday on 27 March were large enough that the fragmentation pattern of lead was readily identifiable (see Fig. 4) and the fragmentation table corrections (see Table 2) due to organic ions were insignificant (less than 6\%) for both $\mathrm{m} / \mathrm{z} 206$ and 208 during the plumes. A non-zero closed signal was observed for $\mathrm{Pb}$, however it was smaller relative to

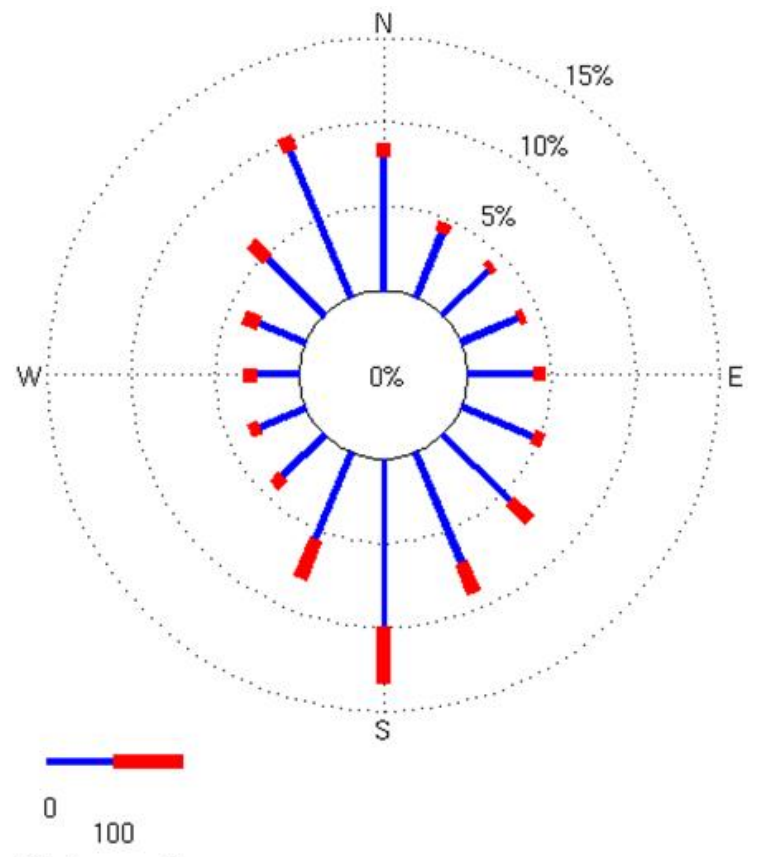

$\mathrm{Pb}\left(\mathrm{ng} \mathrm{am}{ }^{-3}\right)$

Fig. 14. Wind rose using Radar Wind Profiler (RWP) data up to $500 \mathrm{~m}$ of the boundary layer. The length of the bars around the circle is proportional to the frequency of time that the wind blows from a particular direction. Shown in blue is the data for low $\mathrm{Pb}$ levels $\left(<100 \mathrm{ng} \mathrm{am}^{-3}\right)$ and in red, data for high $\mathrm{Pb}$ levels $\left(>100 \mathrm{ng} \mathrm{am}^{-3}\right)$.

the open signal than at T0. This is probably due to different particle $\mathrm{Pb}$ compositions observed at the two sampling sites. Applying the evaporation model described in Sect. 3.2 and Appendix A) to this data, we estimated that $\sim 70 \%$ of the aerosol $\mathrm{Pb}$ evaporates rapidly from the vaporizer $(\tau<0.1 \mathrm{~s})$ and the rest evaporates more slowly with a decay constant 


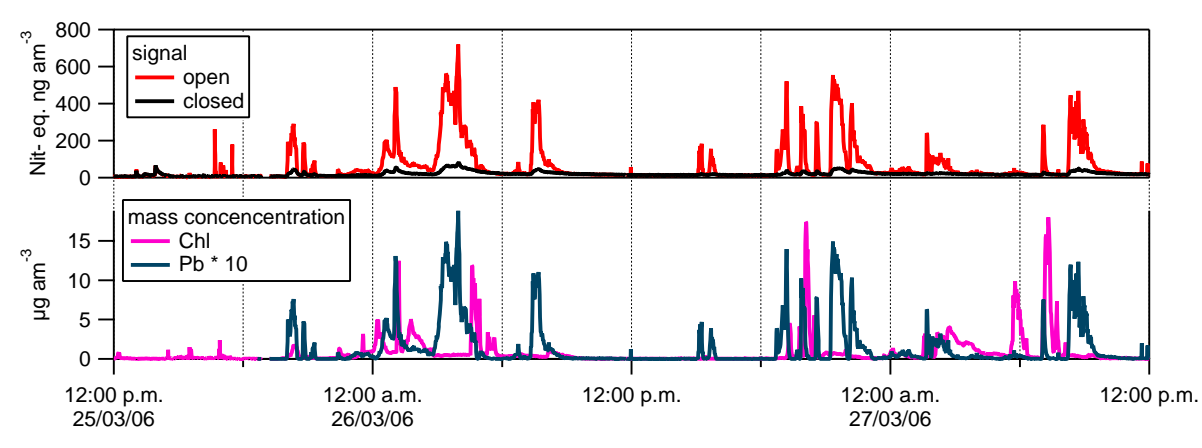

Fig. 15. Top panel: Time series of C-AMS Pb open and closed signals at the PEMEX site. Bottom panel: Mass concentration of Pb compared with particle Chloride at the same site.

of $\sim 0.0003 \mathrm{~s}^{-1}(\tau \sim 56 \mathrm{~min})$; i.e., the less refractory $\mathrm{PM} \mathrm{Pb}$ fraction observed at the PEMEX is larger than at T0, while the more refractory fraction has a larger evaporation time.

$\mathrm{Pb}$ mass concentration was derived from the "input" signal calculated with the model and using $\mathrm{RIE}_{\mathrm{Pb}}=0.5$ per Sect. 3.3. Time series of particle $\mathrm{Pb}$ and chloride mass concentration at the PEMEX site are presented in Fig. 15, bottom panel. During this approximately 2-day period, the C-AMS measured an average $\mathrm{PM} \mathrm{Pb}$ concentration of $139 \mathrm{ng} \mathrm{am}^{-3}$ and recorded $\sim 9$ particulate lead plumes, indicating a strong, perhaps local, source. Similar elevated PM Pb loadings were observed by Querol et al. (2008) obtained in the same site (see Fig. 1). Although large plumes of chloride were also observed at the PEMEX site, there is no obvious correlation between the $\mathrm{Pb}$ and chloride plumes. The much larger particulate chloride than lead concentration also indicates that most of the measured chloride at this site comes from species other than lead chloride. Thus, while these two species have mostly disjoint sources, it is possible that some or all of the measured particulate lead at the PEMEX site was present in the particles as $\mathrm{PbCl}_{2}$.

While CFA analysis of the PEMEX measurements are not applicable in this case due to the short measurement time and to substantial local wind variability, RWP winds show flow from the south during high $\mathrm{Pb}$ and $\mathrm{Cl}$ episodes which was very slow and variable. Based on the observed plume durations and wind speeds, the horizontal extent of the plumes is on the order of $0.3-1 \mathrm{~km}$, which implies that the source cannot be located very far from the PEMEX site. Based on this, a local $\mathrm{Pb}$ source is probably located south of the PEMEX site, and the chloride plumes are probably due to a different source in the same general direction. The $\mathrm{Pb}$ source could possibly be the same that produces the $\mathrm{PbCl}^{+}$signals at $\mathrm{T} 0$ (see Fig. 13).

\section{Conclusions}

Signals corresponding to particle lead were detected with an HR-AMS at T0 and with a C-AMS at PEMEX during MILAGRO. The observation of relatively high closed signals of the lead ions suggests that, because of the low volatility of the lead compounds they are trapped on the vaporizer from which $\mathrm{Pb}$ desorbs slowly. A model was developed to describe this process and to estimate the ambient particle signal sampled by the AMS from the open and closed measurements. Applying the model to ambient lead data at T0 suggests the presence of at least two lead fractions which desorb fast and slowly (1/e decay times, $0.1 \mathrm{~s}$ and $2.4 \mathrm{~min}$, respectively). The estimated decay constants and relative amount of each lead fraction might depend on several factors such as vaporizer temperature and aerosol composition; hence, more information is needed in order to understand the evaporation processes in further detail. Laboratory experiments show that pure $\mathrm{Pb}\left(\mathrm{NO}_{3}\right)_{2}$ particles generate a closed signal in the AMS, and that the signal remains detectable for some time after $\mathrm{Pb}$-containing particles have stopped entering the AMS. Analysis of the laboratory data yield an estimated $\mathrm{RIE}_{\mathrm{Pb}}$ value of 0.5 . The mass concentrations calculated for the HR-AMS using this value were in good agreement with other co-located measurements. The levels of $\mathrm{Pb}$ in fine particles in Mexico City during MILAGRO were about $1 / 2$ of the revised US EPA ambient standard for TSP.

During some periods at T0, particles were sampled through a particle concentrator, which allowed the detection of $\mathrm{PbCl}^{+}$and $\mathrm{PbS}^{+}$ions. Open and closed signals were observed for $\mathrm{PbS}^{+}$; however, closed signals for $\mathrm{PbCl}^{+}$were very small, as is usually observed for non-refractory species. This observation is consistent with the species that produce $\mathrm{PbCl}^{+}$being more volatile than those that produce $\mathrm{PbS}^{+}$. The detection of both lead compounds is consistent with the model results regarding the existence of two $\mathrm{Pb}$ fractions with different volatility, although other $\mathrm{Pb}$-containing species may also be present in the Mexico City aerosol.

The high time resolution of the HR-AMS $\mathrm{Pb}$ measurements enabled a wind direction and back-trajectory-driven 
analysis of likely source locations and strengths. Time series and diurnal cycles of $\mathrm{Pb}$, analysis of the aerosol composition, and CFA and RWP analysis all suggest the existence of different urban-located sources of $\mathrm{Pb}$ affecting the MCMA. As mentioned before, possible $\mathrm{Pb}$ sources include mining, smelters, foundries, industrial fuel combustion, solid waste incineration, unpaved road dust, and emissions from some types of aircraft and race cars that continue using leaded gasoline (Harris and Davidson, 2005; Heal et al., 2005; Lough et al., 2005; EPA, 2006; Murphy et al., 2007; Kummer et al., 2009; Reff et al., 2009). In the MCMA, with the exception of the Tula refinery located Northwest (see Fig. S1), there are no obvious large facilities that could be identified as $\mathrm{Pb}$ sources. A close analysis of the wind patterns and time series of $\mathrm{Pb}$ and $\mathrm{SO}_{2}$ plumes from Tula (deFoy et al., 2009b) observed at $\mathrm{T} 0$ suggests that $\mathrm{Pb}$ plumes do not have their origin at the refinery. From CFA and RWP analysis, a strong particulate lead source is estimated to be located $\mathrm{S} / \mathrm{SW}$ of T0 within the MCMA basin and another one (or more) between T0 and PEMEX site; an additional source may be located north of the PEMEX site and east of T0. AMS measurements of various particulate lead closed/open signals and HR-AMS measurements behind an aerosol concentrator indicate that the observed particulate lead sources likely generate particulate $\mathrm{Pb}$ with different compositions (i.e., observed different likely sources for $\mathrm{PbS}^{+}$and $\mathrm{PbCl}^{+}$ions). Given the large variety of small industries located in and around the MCMA, it is not possible, from the information at hand, to identify specific sources of $\mathrm{Pb}$. In fact, the variable composition of the $\mathrm{Pb}$ plumes observed at $\mathrm{T} 0$ (sometimes correlating with $\mathrm{HOA}$, LOA, chloride or $\mathrm{Zn}^{+}$) suggests the presence of more than one source emitting lead to the atmosphere. This should be the focus of future research.

Figure 1 suggests that levels of particle $\mathrm{Pb}$ in and around the MCMA probably remain within the Mexican standard and within the more strict US standard; with the exception of some specific sites located in the North, including the PEMEX site, which shows $\mathrm{Pb}$ concentrations larger than the US standard level. Efforts should be made to identify the specific $\mathrm{Pb}$ emitters that cause these large local $\mathrm{Pb}$ concentrations in order to reduce the risk of $\mathrm{Pb}$ health effects on the population exposed.

\section{Appendix A}

\section{Vaporizer model}

The model assumes an incoming mass flux of $\mathrm{Pb}\left(\mathrm{Pb}_{\text {in }}\right.$, $\mu \mathrm{g} \mathrm{s}^{-1}$ ) being sampled by the AMS which impacts the vaporizer and sticks to it. Then, $\mathrm{Pb}$ atoms/species desorb from the vaporizer with a rate that is proportional to the mass of $\mathrm{Pb}$ present on the vaporizer. The rate of change of the accumulated mass $\left(P b_{A}, \mu \mathrm{g}\right)$ on the vaporizer is:

$$
\frac{d \mathrm{~Pb}_{\mathrm{A}}}{d t}=\dot{\mathrm{Pb}}_{\mathrm{in}}-k \mathrm{~Pb}_{\mathrm{A}}
$$

where $k$ is a first order decay constant $\left(\mathrm{s}^{-1}\right)$, and $\left(k \mathrm{~Pb}_{\mathrm{A}}\right)$ represents the rate at which $\mathrm{Pb}$ is desorbing from the vaporizer. Solving Eq. (A1) for a given time interval of length $\Delta t$, with constant $\dot{\mathrm{Pb}}_{\text {in }}$, we obtain:

$\mathrm{Pb}_{\mathrm{A}, \mathrm{f}}=\frac{\dot{\mathrm{Pb}} \dot{\mathrm{in}}_{\mathrm{in}}\left(1-e^{-k \Delta t}\right)}{k}+\mathrm{Pb}_{\mathrm{A}, \mathrm{i}} e^{-k \Delta t}$

where $\mathrm{Pb}_{\mathrm{A}, \mathrm{i}}$ and $\mathrm{Pb}_{\mathrm{A}, \mathrm{f}}$ represent the mass of $\mathrm{Pb}$ accumulated on the vaporizer at the beginning and end of the time interval under consideration, respectively. A mass balance on the vaporizer indicates that the difference between the incoming and desorbing mass should be equal to the difference between the accumulated mass at the beginning and end of the time interval:

$\left(\dot{\mathrm{Pb}}_{\mathrm{in}}-\dot{\mathrm{Pb}}_{\mathrm{obs}}\right) \Delta t=\mathrm{Pb}_{\mathrm{A}, \mathrm{f}}-\mathrm{Pb}_{\mathrm{A}, \mathrm{i}}$

where $\mathrm{Pb}_{\mathrm{obs}}$ is the rate of $\mathrm{Pb}$ mass desorbing from the vaporizer $\left(\mu \mathrm{g} \mathrm{s}^{-1}\right)$ which is measured by the signal detected by the mass spectrometer. Using Eqs. (A2) and (A3) it is possible to calculate $\dot{\mathrm{Pb}}_{\text {in }}$ from $\dot{\mathrm{Pb}}_{\mathrm{obs}}$, as long as $k$ is known:

$\dot{\mathrm{Pb}}_{\mathrm{obs}}=\dot{\mathrm{Pb}}_{\mathrm{in}}-\frac{\mathrm{Pb}_{\mathrm{A}, \mathrm{f}}-\mathrm{Pb}_{\mathrm{A}, \mathrm{i}}}{\Delta t}$

The model can be modified if one assumes that the incoming signal of $\mathrm{Pb}$ has two fractions with different desorbing constants. In this case:

$$
\begin{aligned}
& \dot{\mathrm{Pb}}_{\mathrm{obs}}=\left(a \dot{\mathrm{Pb}}_{\mathrm{in}}-\frac{\mathrm{Pb}_{\mathrm{A} 1, \mathrm{f}}-\mathrm{Pb}_{\mathrm{A} 1, \mathrm{i}}}{\Delta t}\right) \\
& +\left((1-a) \dot{\mathrm{Pb}}_{\mathrm{in}}-\frac{\mathrm{Pb}_{\mathrm{A} 2, \mathrm{f}}-\mathrm{Pb}_{\mathrm{A} 2, \mathrm{i}}}{\Delta t}\right)
\end{aligned}
$$

where coefficient $a$ corresponds to the fraction of total signal that corresponds to component 1 and $\mathrm{Pb}_{\mathrm{A} 1}$ and $\mathrm{Pb}_{\mathrm{A} 2}$ are the amount of components 1 and 2 accumulated on the vaporizer, respectively. Equation (A2) can be applied independently to each fraction in order to calculate its desorption profile.

\section{Supplementary material related to this article is available online at: \\ http://www.atmos-chem-phys.net/10/5371/2010/ acp-10-5371-2010-supplement.pdf.}

Acknowledgements. We thank X. Querol and T. Moreno (CSICIDAEA), R. Moffet (LBNL), and A. Laskin (PNNL) for providing the ICP-MS, ATOFMS, and PIXE data, respectively, and J. Kroll (MIT) for useful discussions. We also thank C. Sioutas (USC) and his group for the ongoing collaboration on the use of the mini-VACES aerosol concentrator. This work was supported by the US National Science Foundation (grants ATM-0449815, ATM0528634, ATM-0810950, and ATM-0528227), the US Department 
of Energy (BER/ASP grant DE-FG02-05-ER63981 and ER63980), NOAA OGP (grant NA08OAR4310565) and Comisión Ambiental Metropolitana (México).

Edited by: S. Madronich

\section{References}

Adachi, K. and Buseck, P. R.: Hosted and Free-Floating MetalBearing Atmospheric Nanoparticles in Mexico City, Environm. Sci. Technol., 44, 2299-2304, doi:10.1021/es902505b, 2010.

Aiken, A. C., DeCarlo, P. F., Kroll, J. H., Worsnop, D. R., Huffman, J. A., Docherty, K., Ulbrich, I. M., Mohr, C., Kimmel, J. R., Sueper, D., Zhang, Q., Sun, Y., Trimborn, A., Northway, M., Ziemann, P. J., Canagaratna, M. R., Onasch, T. B., Alfarra, R., Prevot, A.S.H., Dommen, J., Duplissy, J., Metzger, A., Baltensperger, U., and Jimenez, J. L.: O/C and OM/OC Ratios of Primary, Secondary, and Ambient Organic Aerosols with High Resolution Time-of-Flight Aerosol Mass Spectrometry, Environ. Sci. Technol., 42, 4478-4485, 2008.

Aiken, A. C., Salcedo, D., Cubison, M. J., Huffman, J. A., DeCarlo, P. F., Ulbrich, I. M., Docherty, K. S., Sueper, D., Kimmel, J. R., Worsnop, D. R., Trimborn, A., Northway, M., Stone, E. A., Schauer, J. J., Volkamer, R. M., Fortner, E., de Foy, B., Wang, J., Laskin, A., Shutthanandan, V., Zheng, J., Zhang, R., Gaffney, J., Marley, N. A., Paredes-Miranda, G., Arnott, W. P., Molina, L. T., Sosa, G., and Jimenez, J. L.: Mexico City aerosol analysis during MILAGRO using high resolution aerosol mass spectrometry at the urban supersite (T0) - Part 1: Fine particle composition and organic source apportionment, Atmos. Chem. Phys., 9, 66336653, doi:10.5194/acp-9-6633-2009, 2009.

Aiken, A. C., de Foy, B., Wiedinmyer, C., DeCarlo, P. F., Ulbrich, I. M., Wehrli, M. N., Szidat, S., Prevot, A. S. H., Noda, J., Wacker, L., Volkamer, R., Fortner, E., Wang, J., Laskin, A., Shutthanandan, V., Zheng, J., Zhang, R., Paredes-Miranda, G., Arnott, W. P., Molina, L. T., Sosa, G., Querol, X., and Jimenez, J. L.: Mexico city aerosol analysis during MILAGRO using high resolution aerosol mass spectrometry at the urban supersite (T0) - Part 2: Analysis of the biomass burning contribution and the non-fossil carbon fraction, Atmos. Chem. Phys., 10, 5315-5341, doi:10.5194/acp-10-5315-2010, 2010.

Allan, J. D., Alfarra, M. R., Bower, K. N., Williams, P. I., Gallagher, M. W., Jimenez, J. L., McDonald, A. G., Nemitz, E., Canagaratna, M. R., Jayne, J. T., Coe, H., and Worsnop, D. R.: Quantitative sampling using an Aerodyne aerosol mass spectrometer, 2. Measurements of fine particulate chemical composition in two UK cities, J. Geophys. Res., 108, 4099-4105, 2003.

Allan, J. D., Coe, H., Bower, K. N., Alfarra, M. R., Delia, A. E., Jimenez, J. L., Middlebrook, A. M., Drewnick, F., Onasch, T. B., Canagaratna, M. R., Jayne, J. T., and Worsnop, D. R.: Technical Note: Extraction of Chemically Resolved Mass Spectra from Aerodyne Aerosol Mass Spectrometer Data, J. Aerosol Sci., 35, 909-922, 2004.

Aragón-Piña, A., Torres-Villaseñor, G., Monroy-Fernández, M., Luszczewski-Kudra, A., and Leyva-Ramos, R.: Scanning electron microscope and statistical analysis of suspended heavy metal particles in San Luis Potosi, Mexico, Atmos. Environ., 34, 4103-4112, 2000.
Canagaratna, M. R., Jayne, J. T., Jimenez, J. L., Allan, J. D., Alfarra, M. R., Zhang, Q., Onasch, T. B., Drewnick, F., Coe, H., Middlebrook, A., Delia, A., Williams, L. R., Trimborn, A. M., Northway, M. J., DeCarlo, P. F., Kolb, C. E., Davidovits, P., and Worsnop, D. R.: Chemical and microphysical characterization of ambiente aerosols with the Aerodyne aerosol mass spectrometer, Mass Spectrom. Rev. , 26, 185-222, 2007.

Cziczo, D. J., Stetzer, O., Worringen, A., Ebert, M., Weinbruch, S., Kamphus, M., Gallavardin, S. J., Curtius, J., Borrmann, S., Froyd, K. D., Mertes, S., Möhler, O., and Lohmann, U.: Inadvertent climate modification due to anthropogenic lead, Nat. Geosci., 2, 333-336, doi:10.1038/NGEO499, 2009.

DeCarlo, P. F., Kimmel, J. R., Trimborn, A., Northway, M. J., Jayne, J. T., Aiken, A. C., Gonin, M., Fuhrer, K., Horvath, T., Docherty, K. S., Worsnop, D. R., and Jimenez, J. L.: Field-Deployable, High-Resolution, Time-of-Flight Aerosol Mass Spectrometer, Anal. Chem., 78, 8281-8289, 2006.

DeCarlo, P. F., Ulbrich, I. M., Crounse, J., de Foy, B., Dunlea, E. J., Aiken, A. C., Knapp, D., Weinheimer, A. J., Campos, T., Wennberg, P. O., and Jimenez, J. L.: Investigation of the sources and processing of organic aerosol over the Central Mexican Plateau from aircraft measurements during MILAGRO, Atmos. Chem. Phys., 10, 5257-5280, doi:10.5194/acp-10-52572010, 2010.

de Foy, B., Lei, W., Zavala, M., Volkamer, R., Samuelsson, J., Mellqvist, J., Galle, B., Martínez, A.-P., Grutter, M., Retama, A., and Molina, L. T.: Modelling constraints on the emission inventory and on vertical dispersion for $\mathrm{CO}$ and $\mathrm{SO}_{2}$ in the Mexico City Metropolitan Area using Solar FTIR and zenith sky UV spectroscopy, Atmos. Chem. Phys., 7, 781-801, doi:10.5194/acp-7781-2007, 2007.

de Foy, B., Fast, J. D., Paech, S. J., Phillips, D., Walters, J. T., Coulter, R. L., Martin, T. J., Pekour, M. S., Shaw, W. J., Kastendeuch, P. P., Marley, N. A., Retama, A., and Molina, L. T.: Basinscale wind transport during the MILAGRO field campaign and comparison to climatology using cluster analysis, Atmos. Chem. Phys., 8, 1209-1224, doi:10.5194/acp-8-1209-2008, 2008.

de Foy, B., Zavala, M., Bei, N., and Molina, L. T.: Evaluation of WRF mesoscale simulations and particle trajectory analysis for the MILAGRO field campaign, Atmos. Chem. Phys., 9, 44194438, doi:10.5194/acp-9-4419-2009, 2009a.

de Foy, B., Krotkov, N. A., Bei, N., Herndon, S. C., Huey, L. G., Martínez, A.-P., Ruiz-Suárez, L. G., Wood, E. C., Zavala, M., and Molina, L. T.: Hit from both sides: tracking industrial and volcanic plumes in Mexico City with surface measurements and $\mathrm{OMI} \mathrm{SO}_{2}$ retrievals during the MILAGRO field campaign, Atmos. Chem. Phys., 9, 9599-9617, doi:10.5194/acp-9-9599-2009, $2009 b$.

deLaeter, J. R., Böhlke, J. K., deBièvre, P., Hidaka, H., Peiser, H. S., Rosman, K. J. R., and Taylor, P. D. P.: Atomic weights of the elements: review 2000 (IUPAC Technical Report), Pure Appl. Chem., 75, 683-800, 2003.

Doran, J. C., Barnard, J. C., Arnott, W. P., Cary, R., Coulter, R., Fast, J. D., Kassianov, E. I., Kleinman, L., Laulainen, N. S., Martin, T., Paredes-Miranda, G., Pekour, M. S., Shaw, W. J., Smith, D. F., Springston, S. R., and Yu, X.-Y.: The T1-T2 study: evolution of aerosol properties downwind of Mexico City, Atmos. Chem. Phys., 7, 1585-1598, doi:10.5194/acp-7-1585-2007, 2007. 
Doran, J. C., Fast, J. D., Barnard, J. C., Laskin, A., Desyaterik, Y., and Gilles, M. K.: Applications of lagrangian dispersion modeling to the analysis of changes in the specific absorption of elemental carbon, Atmos. Chem. Phys., 8, 1377-1389, doi:10.5194/acp-8-1377-2008, 2008.

Drewnick, F., Hings, S. S., DeCarlo, P., Jayne, J. T., Gonin, M., Fuhrer, K., Weimer, S., Jimenez, J. L., Demerjian, K. L., Borrmann, S., and Worsnop, D. R.: A New Time-of-Flight Aerosol Mass Spectrometer (TOF-AMS) - Instrument Description and First Field Deployment, J. Aerosol Sci., 39, 637-658, 2005.

Dzepina, K., Arey, J., Worsnop, D. R., Salcedo, D., Zhang, Q., Onasch, T. B., Molina, L. T., Molina, M. J., and Jimenez, J. L.: Detection of particle-phase polycyclic aromatic hydrocarbons in Mexico City using an Aerosol Mass Spectrometer, Int. J. Mass Spectrom., 263, 152-170, 2007.

Ebert, M., Weinbruch, S., Rausch, A., Gorzawski, G., Hoffmann, P., Wex, H., and Helas, G.: Complex refractive index of aerosols during LACE 98 as derived from the analysis of individual particles, J. Geophys. Res., 107, 8121, doi:10.1029/2000JD000195, 2002.

EPA: Air quality criteria for lead volume I, US Environmental Protection Agency, 2006.

EPA: National Ambient Air Quality Standards for Lead; Final Rule, US Federal Registry, 73, 66964-67062, 2008.

Ervens, B., Cubison, M. J., Andrews, E., Feingold, G., Ogren, J. A., Jimenez, J. L., Quinn, P. K., Bates, T. S., Wang, J., Zhang, Q., Coe, H., Flynn, M., and Allan, J. D.: CCN predictions using simplified assumptions of organic aerosol composition and mixing state: a synthesis from six different locations, Atmos. Chem. Phys., 10, 4795-4807, doi:10.5194/acp-10-4795-2010, 2010.

Fast, J., Aiken, A. C., Allan, J., Alexander, L., Campos, T., Canagaratna, M. R., Chapman, E., DeCarlo, P. F., de Foy, B., Gaffney, J., de Gouw, J., Doran, J. C., Emmons, L., Hodzic, A., Herndon, S. C., Huey, G., Jayne, J. T., Jimenez, J. L., Kleinman, L., Kuster, W., Marley, N., Russell, L., Ochoa, C., Onasch, T. B., Pekour, M., Song, C., Ulbrich, I. M., Warneke, C., WelshBon, D., Wiedinmyer, C., Worsnop, D. R., Yu, X.-Y., and Zaveri, R.: Evaluating simulated primary anthropogenic and biomass burning organic aerosols during MILAGRO: implications for assessing treatments of secondary organic aerosols, Atmos. Chem. Phys., 9, 6191-6215, doi:10.5194/acp-9-6191-2009, 2009.

Harris, A. R. and Davidson, C.: The Role of Resuspended Soil in Lead Flows in the California South Coast Air Basin, Environ. Sci. Technol., 39, 323-340, 2005.

Heal, M. R., Hibbs, L. R., Agius, R. M., and Beverland, I.J.: Total and water-soluble trace metal content of urban background $\mathrm{PM}_{10}, \mathrm{PM}_{2.5}$ and black smoke in Edinburgh, UK, Atmos. Environ., 39, 1417-1430, 2005.

Heald, C. L., Goldstein, A. H., Allan, J. D., Aiken, A. C., Apel, E., Atlas, E. L., Baker, A. K., Bates, T. S., Beyersdorf, A. J., Blake, D. R., Campos, T., Coe, H., Crounse, J. D., DeCarlo, P. F., de Gouw, J. A., Dunlea, E. J., Flocke, F. M., Fried, A., Goldan, P., Griffin, R. J., Herndon, S. C., Holloway, J. S., Holzinger, R., Jimenez, J. L., Junkermann, W., Kuster, W. C., Lewis, A. C., Meinardi, S., Millet, D. B., Onasch, T., Polidori, A., Quinn, P. K., Riemer, D. D., Roberts, J. M., Salcedo, D., Sive, B., Swanson, A. L., Talbot, R., Warneke, C., Weber, R. J., Weibring, P., Wennberg, P. O., Worsnop, D. R., Wittig, A. E., Zhang, R., Zheng, J., and Zheng, W.: Total observed organic carbon (TOOC) in the atmosphere: a synthesis of North American observations, Atmos. Chem. Phys., 8, 2007-2025, doi:10.5194/acp-8-2007-2008, 2008.

Heald, C. L., Kroll, J. H., Jimenez, J. L., Docherty, K. S., DeCarlo, P. F., Aiken, A. C., Chen, Q., Martin, S. T., Farmer, D. K., Artaxo, P., Weinheimer, A. J.: A simplified description of organic aerosol composition and implications for atmospheric aging, Geophys. Res. Lett., 37, L08803, doi:10.1029/2010GL042737, 2010.

Herndon, S. C., Onasch, T. B., Wood, E. C., Kroll, J. H., Canagaratna, M. R., Jayne, J. T., Zavala, M. A., Knighton, W. B., Mazzoleni, C., Dubey, M. K., Ulbrich, I. M., Jimenez, J. L., Seila, R., deGouw, J. A., deFoy, B., Fast, J., Molina, L. T., Kolb, C. E., and Worsnop, D. R.: Correlation of secondary organic aerosol with odd oxygen in Mexico City, Geophys. Res. Lett., 35, L15804, doi:10.1029/2008GL034058, 2008.

Hodzic, A., Jimenez, J. L., Madronich, S., Aiken, A. C., Bessagnet, B., Curci, G., Fast, J., Lamarque, J.-F., Onasch, T. B., Roux, G., Schauer, J. J., Stone, E. A., and Ulbrich, I. M.: Modeling organic aerosols during MILAGRO: importance of biogenic secondary organic aerosols, Atmos. Chem. Phys., 9, 6949-6981, doi:10.5194/acp-9-6949-2009, 2009.

Hodzic, A., Jimenez, J. L., Madronich, S., Canagaratna, M. R., DeCarlo, P. F., Kleinman, L., and Fast, J.: Potential contribution of semi-volatile and intermediate volatility primary organic compounds to secondary organic aerosol in the Mexico City region, Atmos. Chem. Phys. Discuss., 10, 657-710, doi:10.5194/acpd10-657-2010, 2010.

Hong, S. Y., Noh, Y., and Dudhia, J.: A new vertical diffusion package with an explicit treatment of entrainment processes, Mon. Weather Rev., 134, 2318-2341, 2006.

Huffman, J. A., Docherty, K. S., Mohr, C., Cubison, M. J., Ulbrich, I. M., Ziemann, P. J., Onasch, T. B., and Jimenez, J. L.: Chemically-Resolved Volatility Measurements of Organic Aerosol from Different Sources, Environ. Sci. Technol., 43, 5351-5357, 2009.

Ishizaka, T., Tohno, S., Mab, C.-J., Morikawa, A., Takaoka, M., Nishiyama, F., and Yamamoto, K.: Reactivity between $\mathrm{PbSO}_{4}$ and $\mathrm{CaCO}_{3}$ particles relevant to the modification of mineral particles and chemical forms of $\mathrm{Pb}$ in particles sampled at two remote sites during an Asian dust event, Atmos. Environ., 43, 2550-2560, 2009.

Jayne, J. T., Leard, D. C., Zhang, X., Davidovits, P., Smith, K. A., Kolb, C. E., and Worsnop, D. R.: Development of an Aerosol Mass Spectrometer for Size and Composition Analysis of Submicron Particles, J. Aerosol Sci., 33, 49-70, 2000.

Jimenez, J. L., Jayne, J. T., Shi, Q., Kolb, C. E., Worsnop, D. R., Yourshaw, I., Seinfeld, J. H., Flagan, R. C., Zhang, X., Smith, K. A., Morris, J., and Davidovits, P.: Ambient aerosol sampling using the Aerodyne Aerosol Mass Spectrometer, J. Geophys. Res., 108, 8425, doi:10.1029/2001JD001213, 2003.

Johnson, K. S., Laskin, A., Jimenez, J. L., Shutthanandan, V., Molina, L. T., Salcedo, D., Dzepina, K., and Molina, M. J.: Comparative analysis of urban atmospheric aerosol by particleinduced X-ray emission (PIXE), proton elastic scattering analysis (PESA), and aerosol mass spectrometry (AMS), Environ. Sci. Technol., 42, 6619-6624, 2008. 
Khlystov, A., Zhang, Q., Jimenez, J. L., Stanier, C., Pandis, S. N., Canagaratna, M. R., Fine, P., Misra, C., and Sioutas, C.: In situ concentration of semi-volatile aerosol using water-condensation technology, J. Aerosol Sci., 36, 866-880, 2005.

Kim, S., Jaques, P. A., Chang, M. C., Froines, J. R., and Sioutas, C.: Versatile aerosol concentration enrichment system (VACES) for simultaneous in vivo and in vitro evaluation of toxic effects of ultrafine, fine and coarse ambient particles - Part I: development and laboratory characterization, J. Aerosol Sci., 32, 1281-1297, 2001.

Kleinman, L. I., Springston, S. R., Daum, P. H., Lee, Y.-N., Nunnermacker, L. J., Senum, G. I., Wang, J., Weinstein-Lloyd, J., Alexander, M. L., Hubbe, J., Ortega, J., Canagaratna, M. R., and Jayne, J.: The time evolution of aerosol composition over the Mexico City plateau, Atmos. Chem. Phys., 8, 1559-1575, doi:10.5194/acp-8-1559-2008, 2008.

Kolb, C. E., Herndon, S. C., McManus, J. B., Shorter, J. H., Zahniser, M. S., Nelson, D. D., Jayne, J. T., Canagaratna, M. R., and Worsnop, D. R.: Mobile Laboratory with Rapid Response Instruments for Real-Time Measurements of Urban and Regional Trace Gas and Particulate Distributions and Emission Source Characteristics, Environ. Sci. Technol., 21, 5694-5703, 2004.

Kummer, U., Pacyna, J., Pacyna, E., and Friedrich, R.: Assessment of heavy metal releases from the use phase of road transport in Europe, Atmos. Environ., 43, 640-647, 2009.

Lough, G. C., Schauer, J. J., Park, J.-S., Shafer, M. M., Deminter, J. T., and Weinstein, J. P.: Emissions of Metals Associated with Motor Vehicle Roadways, Environ. Sci. Technol., 39, 826-836, 2005.

McCartney, P. C. E., Shah, M. B., Geddes, J., and Gilbody, H. B.: Multiple ionization of lead by electron impact, J. Phys. B. Atom. M. P., 31, 4821-4831, 1998.

Miranda, J., Barrera, V. A., Espinosa, A. A., Galindo, O. S., NúñezOrosco, A., Montesinos, R. C., Leal-Castro, A., and Meinguer, J.: PIXE analysis of atmospheric aerosols from three sites in Mexico City, Nucl. Instrum. Meth. B., 219-220, 157-160, 2004.

Moffet, R. C., Desyaterik, Y., Hopkins, R. J., Tavanski, A. V., Gilles, M. K., Wang, Y., Shutthanandan, V., Molina, L. T., Gonzalez, R., Johnson, K. S., Mugica, V., Molina, M. J., Laskin, A., and Prather, K. A.: Characterization of Aerosols Containing Zn, $\mathrm{Pb}$, and $\mathrm{Cl}$ from an, Industrial Region of Mexico City, Environ. Sci. Technol., 42, 7091-7097, 2008a.

Moffet, R. C., de Foy, B., Molina, L. T., Molina, M. J., and Prather, K. A.: Measurement of ambient aerosols in northern Mexico City by single particle mass spectrometry, Atmos. Chem. Phys., 8, 4499-4516, doi:10.5194/acp-8-4499-2008, 2008b.

Molina, L. T., Madronich, S., Gaffney, J. S., Apel, E., de Foy, B., Fast, J., Ferrare, R., Herndon, S., Jimenez, J. L., Lamb, B., Osornio-Vargas, A. R., Russell, P., Schauer, J. J., Stevens, P. S., and Zavala, M.: An overview of the MILAGRO 2006 campaign: Mexico City emissions and their transport and transformation, Atmos. Chem. Phys. Discuss., 10, 7819-7983, doi:10.5194/acpd-10-7819-2010, 2010.

Moreno, T., Querol, X., Pey, J., Minguillón, M. C., Pérez, N., Alastuey, A., Bernabé, R. M., Blanco, S., Cárdenas, B., Eichinger, W., Salcido, A., and Gibbons, W.: Spatial and temporal variations in inhalable $\mathrm{CuZnPb}$ aerosols within the Mexico City pollution plume, J. Environ. Monitor., 10, 370-378, 2008.
Mugica, V., Ortiz, E., Molina, L., DeVizcaya-Ruiz, A., Nebot, A., Quintana, R., Aguilar, J., and Alcántara, E.: PM composition and source reconciliation in Mexico City, Atmos. Environ., 2009, 5068-5074, 2009.

Murphy, D. M., Hudson, P. K., Cziczo, D. J., Gallavardin, S., Froyd, K. D., Johnston, M. V., Middlebrook, A. M., Reinard, M. S., Thomson, D. S., Thornberry, T., and Wexler, A. S.: Distribution of lead in single atmospheric particles, Atmos. Chem. Phys., 7, 3195-3210, doi:10.5194/acp-7-3195-2007, 2007.

NOAA: CAMEO Chemicals, Database of Hazardous Materials, National Oceanographic and Atmospheric Administration, http: //cameochemicals.noaa.gov/, last access: 16 June 2010.

Nriagu, J. O.: The rise and fall of leaded gasoline, Sci. Total Environ., 92, 13-28, 1990.

Pacyna, J. M., Pacyna, E. G., and Aas, W.: Changes of emissions and atmospheric deposition of mercury, lead, and cadmium, Atmos. Environ., 43, 117-127, 2009.

Paredes-Miranda, G., Arnott, W. P., Jimenez, J. L., Aiken, A. C., Gaffney, J. S., and Marley, N. A.: Primary and secondary contributions to aerosol light scattering and absorption in Mexico City during the MILAGRO 2006 campaign, Atmos. Chem. Phys., 9, 3721-3730, doi:10.5194/acp-9-3721-2009, 2009.

Querol, X., Pey, J., Minguillón, M. C., Pérez, N., Alastuey, A., Viana, M., Moreno, T., Bernabé, R. M., Blanco, S., Cárdenas, B., Vega, E., Sosa, G., Escalona, S., Ruiz, H., and Artíñano, B.: PM speciation and sources in Mexico during the MILAGRO-2006 Campaign, Atmos. Chem. Phys., 8, 111-128, doi:10.5194/acp8-111-2008, 2008.

Reff, A., Bhave, P. V., Simon, H., Pace, T. G., Pouliot, G. A., Mobley, J. D., and Houyoux, M.: Emissions Inventory of $\mathrm{PM}_{2.5}$ Trace Elements across the United States, Environ. Sci. Technol., 43, 5790-5796, 2009.

Rivera, C., Sosa, G., Wöhrnschimmel, H., de Foy, B., Johansson, M., and Galle, B.: Tula industrial complex (Mexico) emissions of $\mathrm{SO}_{2}$ and $\mathrm{NO}_{2}$ during the MCMA 2006 field campaign using a mobile mini-DOAS system, Atmos. Chem. Phys., 9, 6351-6361, doi:10.5194/acp-9-6351-2009, 2009.

Rosas-Pérez, I., Serrano, J., Alfaro-Moreno, E., Baumgardner, D., García-Cuellar, C., Miranda, J., delCampo, M., Raga, G. B., Castillejos, M., Colín, R. D., and Osornio-Vargas, A. R.: Relations between $\mathrm{PM}_{10}$ composition and cell toxicity: A multivariate and graphical approach, Chemosphere, 67, 1218-1228, 2007.

Salcedo, D., Onasch, T. B., Dzepina, K., Canagaratna, M. R., Zhang, Q., Huffman, J. A., DeCarlo, P. F., Jayne, J. T., Mortimer, P., Worsnop, D. R., Kolb, C. E., Johnson, K. S., Zuberi, B., Marr, L. C., Volkamer, R., Molina, L. T., Molina, M. J., Cardenas, B., Bernabé, R. M., Márquez, C., Gaffney, J. S., Marley, N. A., Laskin, A., Shutthanandan, V., Xie, Y., Brune, W., Lesher, R., Shirley, T., and Jimenez, J. L.: Characterization of ambient aerosols in Mexico City during the MCMA-2003 campaign with Aerosol Mass Spectrometry: results from the CENICA Supersite, Atmos. Chem. Phys., 6, 925-946, doi:10.5194/acp-6-9252006, 2006.

Seibert, P., Kromp-Kolb, H., Baltensperger, U., Jost, D. T., and Schwikowski, M.: Trajectory analysis of high-alpine air pollution data, in: Air Pollution Modelling and its Application X, edited by: Gryning, S.-E. and Millan, M. M., Plenum Press, 704 p., 1994. 
Shaw, W. J., Pekour, M. S., Coulter, R. L., Martin, T. J., and Walters, J. T.: The daytime mixing layer observed by radiosonde, profiler, and lidar during MILAGRO, Atmos. Chem. Phys. Discuss., 7, 15025-15065, doi:10.5194/acpd-7-15025-2007, 2007.

Skamarock, W. C., Klemp, J. B., Dudhia, J., Gill, D. O., Barker, D. M., Wang, W., and Powers, J.G.: A Description of the Advanced Research WRF Version 2, Technical Report NCAR/TN468+STR, National Center for Atmospheric Research, 2005.

SMA: La calidad del aire en la Zona Metropolitana del Valle de México 1986-2006; Informe del estado y tendencias de la contaminación atmosférica, Secretaria del Medio Ambiente del Gobierno del Distrito Federal, 2007.

Stohl, A., Forster, C., Frank, A., Seibert, P., and Wotawa, G.: Technical note: The Lagrangian particle dispersion model FLEXPART version 6.2, Atmos. Chem. Phys., 5, 2461-2474, doi:10.5194/acp-5-2461-2005, 2005.

Thornhill, D. A., de Foy, B., Herndon, S. C., Onasch, T. B., Wood, E. C., Zavala, M., Molina, L. T., Gaffney, J. S., Marley, N. A., and Marr, L. C.: Spatial and temporal variability of particulate polycyclic aromatic hydrocarbons in Mexico City, Atmos. Chem. Phys., 8, 3093-3105, doi:10.5194/acp-8-3093-2008, 2008.

Ulbrich, I. M., Canagaratna, M. R., Zhang, Q., Worsnop, D. R., and Jimenez, J. L.: Interpretation of organic components from Positive Matrix Factorization of aerosol mass spectrometric data, Atmos. Chem. Phys., 9, 2891-2918, doi:10.5194/acp-9-2891-2009, 2009.

vanMalderen, H., Hoornaert, S., and vanGrieken, R.: Identification of Individual Aerosol Particles Containing $\mathrm{Cr}, \mathrm{Pb}$, and $\mathrm{Zn}$ above the North Sea, Environ. Sci. Technol., 30, 489-498, 1996.
Vega, E., Reyes, E., Ruiz, H., García, J., Sánchez, G., MartínezVilla, G., González, U., Chow, J. C., and Watson, J. G.: Analysis of $\mathrm{PM}_{2.5}$ and $\mathrm{PM}_{10}$ in the Atmosphere of Mexico City during 2000-2002, J. Air Waste Manage. Assoc., 54, 786-798, 2004.

WaveMetrics: ed., IGOR Pro. V6.0. User's Guide, WaveMetrics, Inc., USA, 2008.

Wood, E. C., Canagaratna, M. R., Herndon, S. C., Kroll, J. H., Onasch, T. B., Kolb, C. E., Worsnop, D. R., Knighton, W. B., Seila, R., Zavala, M., Molina, L. T., DeCarlo, P. F., Jimenez, J. L., Weinheimer, A. J., Knapp, D. J., Jobson, B. T., Stutz, J., Kuster, W. C., and Williams, E. J.: Investigation of the correlation between odd oxygen and secondary organic aerosol in Mexico City and Houston, Atmos. Chem. Phys. Discuss., 10, 35473604, doi:10.5194/acpd-10-3547-2010, 2010.

Wood, E. C., Herndon, S. C., Onasch, T. B., Kroll, J. H., Canagaratna, M. R., Kolb, C. E., Worsnop, D. R., Neuman, J. A., Seila, R., Zavala, M., and Knighton, W. B.: A case study of ozone production, nitrogen oxides, and the radical budget in Mexico City, Atmos. Chem. Phys., 9, 2499-2516, doi:10.5194/acp-9-2499-2009, 2009.

Zavala, M., Herndon, S. C., Wood, E. C., Jayne, J. T., Nelson, D. D., Trimborn, A. M., Dunlea, E., Knighton, W. B., Mendoza, A., Allen, D. T., Kolb, C. E., Molina, M. J., and Molina, L. T.: Comparison of emissions from on-road sources using a mobile laboratory under various driving and operational sampling modes, Atmos. Chem. Phys., 9, 1-14, doi:10.5194/acp-9-1-2009, 2009.

Zheng, J., Zhang, R., Fortner, E. C., Volkamer, R. M., Molina, L., Aiken, A. C., Jimenez, J. L., Gaeggeler, K., Dommen, J., Dusanter, S., Stevens, P. S., and Tie, X.: Measurements of $\mathrm{HNO}_{3}$ and $\mathrm{N}_{2} \mathrm{O}_{5}$ using ion drift-chemical ionization mass spectrometry during the MILAGRO/MCMA-2006 campaign, Atmos. Chem. Phys., 8, 6823-6838, doi:10.5194/acp-8-6823-2008, 2008. 